\title{
Expression of special AT-rich sequence-binding protein 1 is an independent prognostic factor in cutaneous T-cell lymphoma
}

\author{
DARIUSZ GRZANKA $^{1}$, MACIEJ GAGAT ${ }^{2}$, MAGDALENA IZDEBSKA $^{2}$ and ANDRZEJ MARSZAŁEK ${ }^{3,4}$
}

\author{
${ }^{1}$ Department and Clinic of Dermatology, Sexually Transmitted Diseases and Immunodermatology; \\ Departments of ${ }^{2}$ Histology and Embryology, and ${ }^{3}$ Clinical Pathomorphology, Nicolaus Copernicus University in Torun, \\ Collegium Medicum in Bydgoszcz, 85-092 Bydgoszcz; ${ }^{4}$ Department of Oncologic Pathology, \\ Poznan University of Medical Sciences and Greater Poland Oncology Center, Poznan, Poland
}

Received May 26, 2014; Accepted August 28, 2014

DOI: $10.3892 / o r .2014 .3597$

\begin{abstract}
Cutaneous T-cell lymphoma (CTCL) is a group of slowly progressive, lymphoproliferative disorders characterized by localization of neoplastic $\mathrm{T}$ lymphocytes to the skin. The most common type of CTCL is mycosis fungoides which has a mild clinical course with slow and long progression. The rate of progression is generally slow and takes many years but often remains unpredictable. Special AT-rich sequencebinding protein-1 (SATB1) is a global chromatin organizer which controls gene expression by folding and remodeling chromatin, but which also regulates the level of histone methylation and acetylation, important in differentiation and apoptosis. The aim of the present study was to determine if SATB1 may be considered a prognostic and predictive factor of CTCL. The results showed that moderate and high expression of SATB1 correlate with significantly better prognosis of CTCL patients. Moreover, we showed that downregulation of SATB1 in Jurkat cells caused their resistance to activationinduced cell death. In conclusion, SATB1 expression appears to be a strong candidate as a prognostic factor confirming the inner heterogeneous features of CTCLs.
\end{abstract}

\section{Introduction}

Cutaneous T-cell lymphoma (CTCL) is a general term for many types of skin lymphomas and it accounts for $71 \%$ of the 3,884 cutaneous lymphomas diagnosed in the United States between 2001 and 2005 (1). Incidence rates (IRs) for all CTCLs in the US population have been estimated to be $4.1-7.7 / 1,000,000$ person-years $(1,2)$. This group of cutaneous lymphomas includes mycosis fungoides (MF), Sézary

Correspondence to: Dr Dariusz Grzanka, Department and Clinic of Dermatology, Sexually Transmitted Diseases and Immunodermatology, Nicolaus Copernicus University in Torun, Collegium Medicum in Bydgoszcz, 24 Karłowicza Street, 85-092 Bydgoszcz, Poland E-mail: d_gr@me.com

Key words: cutaneous T-cell lymphoma, special AT-rich sequencebinding protein-1, prognostic marker, mycosis fungoides, Sézary syndrome, lymphomatoid papulosis syndrome (SS), lymphomatoid papulosis (LyP) and cutaneous anaplastic large cell lymphoma. MF is the most common type of CTCL, characterized by slow progression and with no effective cure (3). In the present study, phototherapy with psoralen plus ultraviolet A (PUVA) with or without biologic therapy have a significant meaning. In the early stages, it is used as a monotherapy, and, in later stages, it is combined with interferon or retinoids. Immunomodulatory treatment is used to reduce side-effects, i.e. interferon $\alpha$, bexarotene, deacetylase inhibitors, denileukin diftitox and methotrexate (4-6). The SS, another frequently occurring and the most aggressive CTCL, is characterized by erythroderma, lymphadenopathy and neoplastic T cells (Sézary cells) in the peripheral blood. The accumulation of these malignant cells contributes to the resistance to apoptosis, in particular, activation-induced cell death (7). This type of disease has a fast clinical course with an unfavorable patient prognosis and comprises $\sim 15 \%$ of the total MF/SS population (8).

Early diagnosis, in all types of lymphoma, is of major clinical significance as it makes treatment possible and it may also inhibit further progression of the disease. The main mechanism of the effect of the drugs is associated with induction of apoptosis in cancer cells (9). Furthermore, some drugs promoted cell growth and differentiation or modulation of immune response to the cancer cells. Therapy is highly important, but the correct classification of cancer allows for the best treatment methods to be selected $(10,11)$.

At present, scientists optimize diagnostic methods and search for new specific markers for primary cutaneous lymphomas, but there is a lack of progression markers and clinical course remains unpredictable in the majority of cases. One marker may be a special AT-rich sequence-binding protein-1 (SATB1), a global chromatin organizer cloned in 1992 (12), which appears to be a potential prognostic marker of CTCL (11). SATB1 controls gene expression by folding and remodeling chromatin and regulating the level of histone methylation and acetylation $(13,14)$. SATB1 is expressed primarily in thymocytes, but a very low expression level has also been found in osteoblasts and testis $(15,16)$. Moreover, SATB1 has been reported to be overexpressed in numerous human tumors, including bladder, prostate and rectal cancer as well as in nasopharyngeal carcinoma (17-20). It is considered 
an indicator of unfavorable prognosis in breast cancer, as the nuclear expression of SATB1 correlates with metastasis to the lymph nodes (20-24). It is known that Sézary cells are deficient in the expression of SATB1, but Wang et al (7) suggested that restoring SATB1 expression in Hut78 cells (in vitro model of Sézary cells) may induce spontaneous cell death and may sensitize cells to the treatment. This suggests that a deficiency in SATB1 expression plays an important role in SS pathogenesis by causing apoptosis resistance. However, little is known regarding the possible role of SATB1 in the prognosis of CTCL patients. Our previous study on a relatively small group of patients with MF suggested that the low level of SATB1 results in an unfavorable prognosis (11).

The aim of the present study was to determine if SATB1 may be considered a prognostic and predictive factor of CTCL. In addition, we also examined the effect of SATB1 downregulation on apoptotic cell death induction in Jurkat cells.

\section{Materials and methods}

Patient selection and staging approach. The studied group consisted of 60 patients with cutaneous lymphoma, including 57 with MF, 2 with SS and 1 with LyP. Written informed consent was obtained from each patient before the tissue sample acquisition, and approval of the study was granted by the institution's Ethics Committee (no. 215/2008). Samples were fixed in $10 \%$ buffered formalin and embedded in paraffin block. All histopathological results were standardized according to the WHO classification (2008) using an immunohistochemical diagnostic panel of antibodies, CD3, CD4, CD7, CD8, CD20, CD30, CD45RO, and the studies conducted confirmed monoclonal growth of the neoplasm using the PCR method. Patients were staged according to TNMB and subsequently according to the ISCL/EORTC proposal. However, to investigate the significance of SATB1 protein as a prognostic factor we concentrated only on T-classification.

SATB1 immunohistochemical staining and quantitation. The classical immunohistochemical reaction was carried out with the use of rabbit monoclonal antibodies against the SATB1 protein (Abcam) and EnVision ${ }^{\mathrm{TM}}$ FLEX Mini kit, High $\mathrm{pH}$ (Dako) on 5- $\mu \mathrm{m}$ paraffin sections placed on the SuperFrost Plus microscopic slides (Thermo Fisher Scientific). The slides were examined using Eclipse E800 microscope (Nikon) with NIS-Elements 3.30 image analysis system and CCD camera (DS-5Mc-U1; Nikon) (Fig. 1). The expression intensities of SATB1 were measured along the expression path as per an intensity scoring scale (0-10) using NIS-Elements 3.30 software (Nikon). A 10-point intensity scoring scale was used considering maximum expression as 10 and minimum expression as 0 . Patients with none or low SATB1 expression (0-2) were considered SATB1-negative, whereas patients with moderate (3-4) and high SATB1 expression (5-10) were considered SATB1-positive. To minimize variations in staining intensity among different experiments, several steps were taken: i) a positive (thymus, LyP) and negative (SS) control were routinely included to check staining procedure; ii) as smooth muscle cells of vessels, fibroblast and epithelial cells are weakly reactive, these cells were applied as internal controls; iii) the same batch of antibody was used for all slides. Immunostaining of SATB1 was independently evaluated by three investigators, and two of them had no previous knowledge of the clinical data. In case of different intensity estimation, the lower score was adopted. Variability between observers was examined among all patients, and was $<5 \%$.

Cell culture and cell death induction. Jurkat E6.1 cells (ATTC) were maintained in RPMI-1640 medium (Lonza Ltd., Basel, Switzerland) supplemented with $10 \%$ heat-inactivated fetal bovine serum (FBS; Gibco, Life Technologies), containing $50 \mu \mathrm{g} / \mathrm{ml}$ gentamycin. The cells were cultured at $37^{\circ} \mathrm{C}$ in a humidified $\mathrm{CO}_{2}$ incubator under $5 \% \mathrm{CO}_{2}$ and $95 \%$ air. For induction of apoptosis, the cell were cultured on $10 \mu \mathrm{g} / \mathrm{ml}$ UCHT-1 CD3 monoclonal antibody (m Ab)-coated plates (BD Pharmingen), treated with $2.5 \mu \mathrm{g} / 50 \mu \mathrm{l}$ DX2 CD95 monoclonal antibody (BD Pharmingen) and $0.5 \mu \mathrm{g} / 50 \mu \mathrm{l}$ recombinant Protein G (Sigma-Aldrich), or in the presence of $10 \mathrm{ng} / \mathrm{ml}$ recombinant human interleukin-2 (IL-2) (SigmaAldrich) for 3 days and treated with $100 \mathrm{ng} / \mathrm{ml}$ phorbol 12-myristate 13-acetate (PMA; Sigma-Aldrich) and $1 \mu \mathrm{g} / \mathrm{ml}$ ionomycin (Io) for $16 \mathrm{~h}$. The control cells were cultured in the same conditions without addition of $\mathrm{mAb}$ or PMA/Io.

Downregulation of SATB1. SATB1 was downregulated in Jurkat E6.1 cells (ATCC) using siRNA SATB1 $_{\text {(corresponding to }}$ sequence 5'-CCCTGTCAGTAGGTCTATGAA-3') obtained from Qiagen. The cells were transfected with siRNA ${ }_{\mathrm{SATB} 1}$ or non-targeting siRNA by electroporation technique using SE Cell Line 4D Nucleofector kit (Lonza) and 4D-Nucleofector Unit (Lonza) according to the manufacturer's instructions. Briefly, the cells were seeded out 2 days before electroporation to a density of $1 \times 10^{5} / \mathrm{ml}$. Then, total of $1 \times 10^{6}$ cells were resuspended in $100 \mu \mathrm{l}$ of SE Nucleofector solution, together with $30 \mathrm{nM}$ of siRNA $_{\text {SATB1 }}$ Qiagen or $2 \mu \mathrm{g}$ pmaxGFP $^{\text {TM }}$ Control Vector (Lonza). The mixture was then transferred into a cuvette provided in the kit and the cells were electroporated using 4D-Nucleofector device (Lonza) with program CL-120. Transfection efficiency was analyzed at the day of the experiments by GFP fluorescence intensity analysis using Tali $^{\circledR}$ Image-based cytometer (Invitrogen, Life Technologies) in cells transfected with pmaxGFP Control Vector (Lonza). Downregulation of SATB1 was confirmed using western blot analysis as previously described (25).

Cell death analysis. The analysis of cell death was performed using Tali Image-based cytometer and Tali Apoptosis kit (both from Invitrogen, Life Technologies) according to the manufacturer's instructions. Briefly, the cells were resuspended in Annexin binding buffer at a concentration of $1 \times 10^{6}$ cell $/ \mathrm{ml}$. Then, $5 \mu \mathrm{l}$ of Annexin V Alexa Fluor 488 was added to each $100 \mu \mathrm{l}$ of sample, mixed and incubated at room temperature in the dark for $20 \mathrm{~min}$. After centrifugation $(5 \min 300 \mathrm{x} \mathrm{g}$ ), the cells were resuspended in $100 \mu \mathrm{l}$ of Annexin $\mathrm{V}$ binding buffer. Then, the cells were incubated with addition of $1 \mu \mathrm{l}$ of propidium iodide (PI) at room temperature in the dark for 3 min. Subsequently, $25 \mu \mathrm{l}$ of stained cells were loaded into a Tali Cellular Analysis Slide (Invitrogen, Life Technologies). The data were analyzed using Flowing software (ver2.5.0; Turku University, Finland) on the assumption that viable cells are both Annexin V Alexa Fluor 488- and PI-negative 

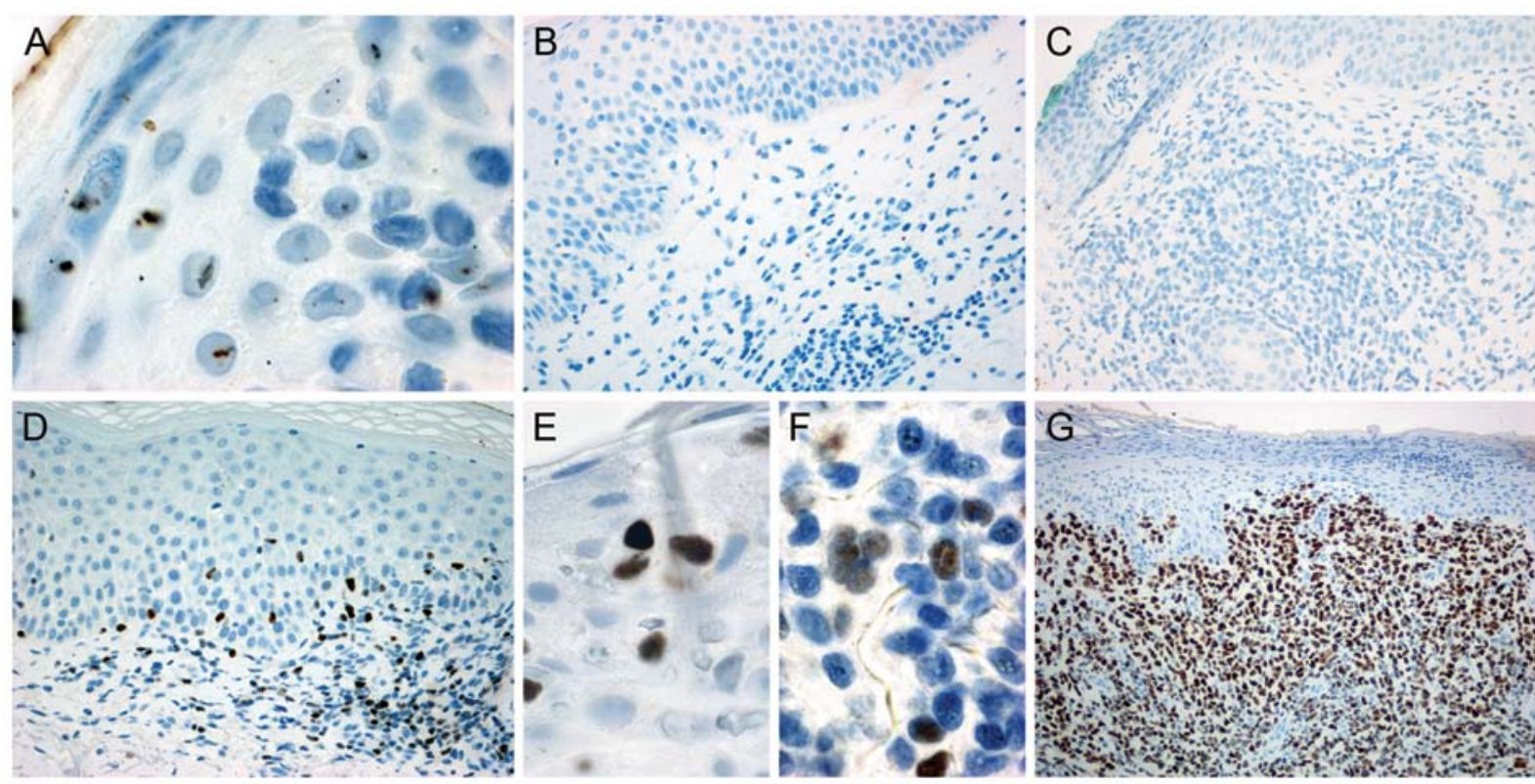

Figure 1. Light microscopic images of immunohistochemical staining for special AT-rich sequence-binding protein-1 (SATB1) in skin tissue specimens of cutaneous T-cell lymphoma (CTCL) patients. (A) Sézary syndrome, negative reaction with SATB1 antibody, cerebriform lymphocytes within epidermis. (B) Mycosis fungoides (MF) (patch stage), negative reaction with SATB1 antibody. (C) MF (plaque stage), negative reaction with SATB1 antibody. (D) MF (patch stage), positive reaction with SATB1 antibody, medium- and small-size lymphocytes. (E) MF positive reaction with SATB1 antibody, collections of mycosis lymphocytes located within the epidermis. (F) MF positive reaction with SATB1 antibody, cerebriform lymphocytes (G) Lymphomatoid papulosis, positive reaction with SATB1 antibody.

cells, apoptotic cells are Annexin V Alexa Fluor 488-positive, whereas necrotic cells are Annexin V Alexa Fluor 488-negative and PI-positive.

Statistical analysis. Jurkat E6.1 cell death data are shown as mean values \pm SEM. Comparisons between different groups of cell death data were performed using a two-tailed Mann-Whitney U test. In the life span study, the data underwent Kaplan-Meier survival analysis, which included use of Gehan-Breslow-Wilcoxon, log-rank (Mentel-Cox) and logrank for trend tests. GraphPad Prism 5.0 (GraphPad Software) was used for statistical analyses and a P-value $<0.05$ was considered to indicate a statistically significant difference.

\section{Results}

Patient characteristics. Clinical characteristics, stage, and mean/median survival are summarized in Table I. The median age at diagnosis was 51 years (range, 28-75 years). Specifically, at the time of diagnosis, $21.67 \%$ of patients were aged $<40$ years, $26.67 \%$ were $40-50$ years old, $28.33 \%$ were 51-60 years old, and $23.33 \%$ were aged $>60$ years. The male to female ratio was 2.33:1. Disease subset was diagnosed as MF (95\%), SS (3.33\%) and LyP (1.67\%). Additionally, clinical and histological variants included folliculotropic MF (1.67\%). The majority of patients $(83.33 \%)$ had T1 (limited patches, papules and/or plaques covering $<10 \%$ of the skin surface) or T2 (covering $\geq 10 \%$ of the skin surface) stage at diagnosis and only $11.67 \%$ had T4 stage (confluence of erythema covering $\geq 80 \%$ of body-surface area). There were no patients diagnosed with T3. According to extended ISCL/EORTC classification, at the time of diagnosis, $56.67 \%$ of total patients had only patches
(T1a), whereas $5 \%$ had patches and plaques (T1b). Similarly, $21.65 \%$ patients were diagnosed in $\mathrm{T} 2 \mathrm{a}$ (patch only) and $5 \%$ in $\mathrm{T} 2 \mathrm{~b}$ (plaque \pm patch).

Patients were also classified according to the expression of SATB1. Thirty-five percent of total patients were deficient in SATB1 or presented low expression, whereas the majority of patients were characterized by moderate or high SATB1 expression $(65 \%)$ and were considered as SATB1-positive.

Overall and disease-specific survival by demographic factors. Results of analysis of changes in survival with regard to demographic factors are shown in Tables I-III, with Kaplan-Meier survival curves in Fig. 2. Median survival was 20.08 years and mean survival varied according to the age at diagnosis and gender. Disease-specific mean survival was the highest for patients aged $>60$ years (20.42 years) and the lowest for patients diagnosed at the range of 40-50 years (18.08 years). Although patients diagnosed at the age of $<40$ years were characterized by the best 20 -year overall survival (OS) (92.31\%), disease-specific survival (DSS) was lower in this patient group than in the group with an age range of 51-60 years $(94.12 \%)$ and $>60$ years $(100 \%)$ (Table I). Moreover, pairwise comparison revealed that patients aged $>60$ years had extremely higher hazard ratio (HR) of DSS ( $\mathrm{HR}=11.26, \mathrm{P}=0.0456)$, as compared to the group diagnosed at the range of 40-50 years (Table III).

Furthermore, DSS was 20.04 years for women and only 19.21 years for men. Similarly, females had better 10- and 20-year OS/DSS (100 and $94.44 \%$ for both OS and DSS, respectively) than men (Table I). Women were more likely to survive, but this was not statistically significant $(\mathrm{HR}=1.77$, $\mathrm{P}=0.1035$ for $\mathrm{OS}$ and $\mathrm{HR}=1.13, \mathrm{P}=0.2030$ for DSS) (Table II). 


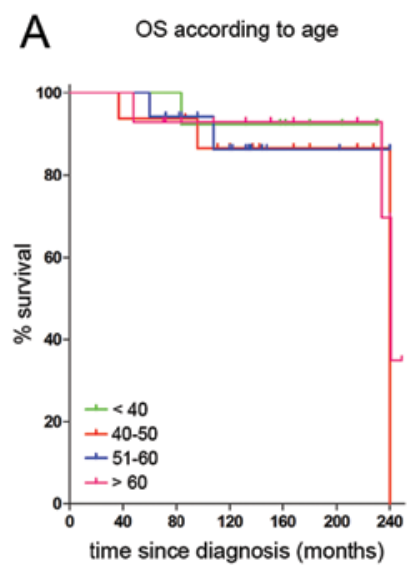

E os according to disease subset

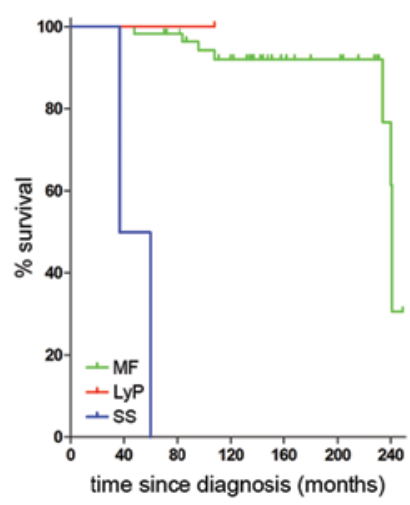

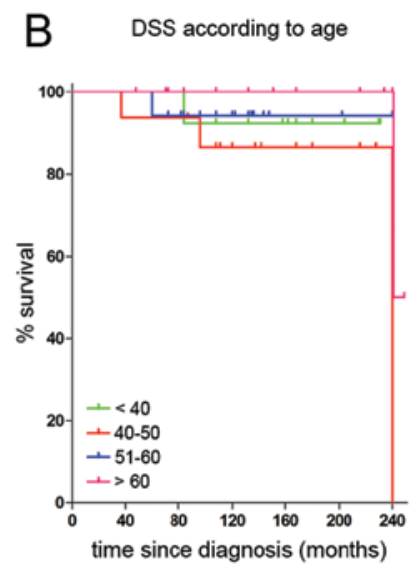

F DSS according to disease subset

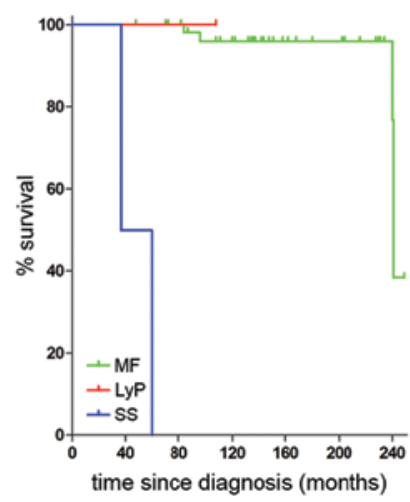

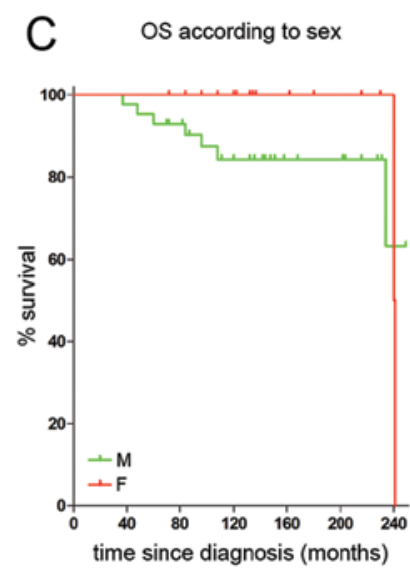

$G$ OS according to T classification

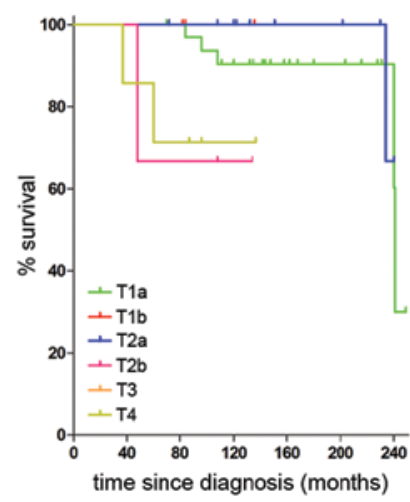

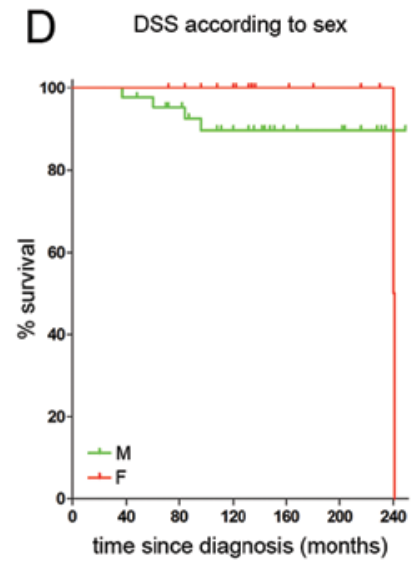

H DSS according to T classification

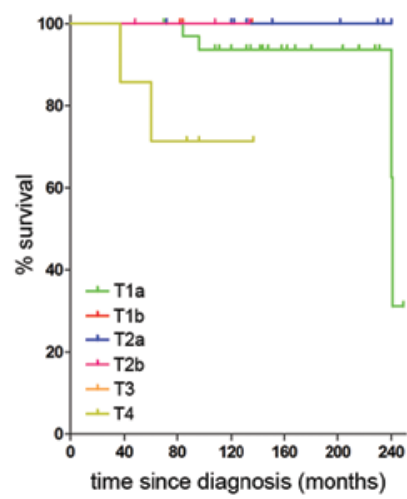

Figure 2. Kaplan-Meier analysis of overall survival (OS) and disease-specific survival (DSS) by age, gender, disease subset and T-classification. (A) OS by age. (B) DSS by age. (C) OS by gender. (D) DSS by gender. (E) OS by disease subset. (F) DSS by disease subset. (G) OS by T-classification. (H) DSS by T-classification.

Overall and disease-specific survival by disease subset and T-classification. Changes in OS and DSS are shown in Tables I-III, with Kaplan-Meier survival curves in Fig. 2. Patients with MF and LyP were characterized by much higher OS and DSS than patients with SS. Moreover, statistically significant differences were noted in HR as compared to MF and LyP or SS $\left(\mathrm{HR}=2.78\right.$ and $\mathrm{HR}=2.9^{-13}, \mathrm{P}<0,0001$, respectively) (Table II).

In addition, mean survival was decreased together with $\mathrm{T}$ stage (19.15 years for patients diagnosed at $\mathrm{T} 1,18.84$ years for T2, and 9.31 years for T3 stage). Similarly, 20-year OS was decreased according to T stage $(89.19 \%$ for T1, $87.50 \%$ for T2, and $71.43 \%$ for T4; Table I); however, the HR analysis showed a statistically significant difference only when comparing $\mathrm{T} 1$ and $\mathrm{T} 4$ stages $(\mathrm{HR}=0.06, \mathrm{P}=0.0224$; Table III $)$. Pairwise comparison of extended T-classification showed statistically significantly lower OS in patients diagnosed in T2a vs. T2b $\left(\mathrm{HR}=4.8^{-3}, \mathrm{P}=0.0374\right)$ and $\mathrm{T} 2 \mathrm{a}$ vs. $\mathrm{T} 4(\mathrm{HR}=0.05, \mathrm{P}=0.0455)$, and in T1a vs. T4 (HR=0.07, $\mathrm{P}=0.0348$; Table III). DSS was the highest for patients with T2 (100\%) and the lowest for T4 stage $(71.43 \%$ ) (Table I). Furthermore, pairwise comparison showed statistically significantly lower DSS in patients with $\mathrm{T} 4$, as compared to $\mathrm{T} 1(\mathrm{HR}=0.04, \mathrm{P}=0.0199)$ and $\mathrm{T} 2(\mathrm{HR}=0.03$, $\mathrm{P}=0.0292$ ) (Table III). Extended T-classification confirmed the above results, but indicated statistically significant differences only between patch stages (T1a or T2a) and $\mathrm{T} 4(\mathrm{HR}=0.05$, $\mathrm{P}=0.0287$ and $\mathrm{HR}=0.05, \mathrm{P}=0.0455$, respectively).
Overall and disease-specific survival by SATB1 expression. Changes in OS and DSS in patients according to SATB1 expression are shown in Tables I-III, with Kaplan-Meier survival curves in Fig. 3. Analysis indicated that both mean survival and disease-specific mean survival were higher in patients characterized with moderate or high expression of SATB1 (increase from 16.35 to 20.02 years and from 17.00 to 20.56 years, respectively; Table I). Similar results were obtained after excluding SS and LyP from SATB1-positive and -negative groups. Moreover, the SATB1-positive patients had increased OS and DSS, as compared to patients with a lack or low SATB1 expression. There was a statistically significant increase in the likelihood of survival in both groups with included $(\mathrm{HR}=6.40, \mathrm{P}=0.0033$ for $\mathrm{OS}$ and $\mathrm{HR}=11.08, \mathrm{P}=0.0033$ for DSS) and excluded SS and $\mathrm{LyP}(\mathrm{HR}=4.38, \mathrm{P}=0.0303$ for $\mathrm{OS}$ and $\mathrm{HR}=7.99, \mathrm{P}=0.0286$ ) (Table II). However, analysis of trend measured in patients classified by SATB1 labeling intensity indicated statistically significant increase of $\mathrm{OS}(\mathrm{HR}=4.83$ for low expression, $\mathrm{HR}=21.45$ for medium expression, $\mathrm{HR}=4.52$ for high expression, $\mathrm{P}=0.0211)$ and $\mathrm{DSS}(\mathrm{HR}=3.84$ for low expression, $\mathrm{HR}=34.62$ for medium expression, $\mathrm{HR}=5.93$ for high expression, $\mathrm{P}=0.0148$ ) only in groups with included $\mathrm{SS}$ and LyP. Furthermore, pairwise comparison showed that patients characterized by moderate expression of SATB1 were more likely to survive than patients without its expression $(\mathrm{HR}=21.45, \mathrm{P}=0.0011)$, and patients with high expression 4.52 times $(\mathrm{P}=0.0104)$, as compared to group without any SATB1 


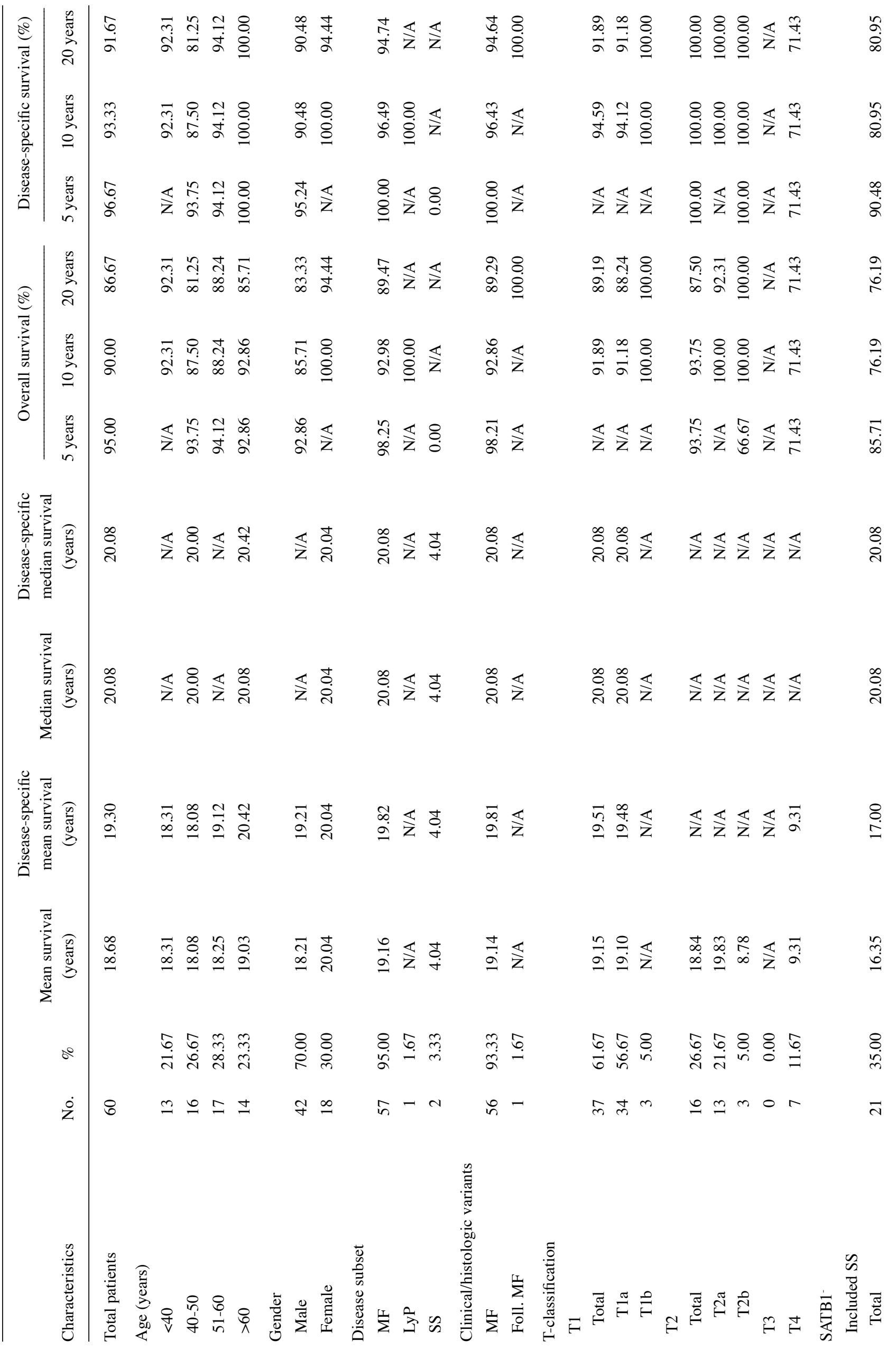




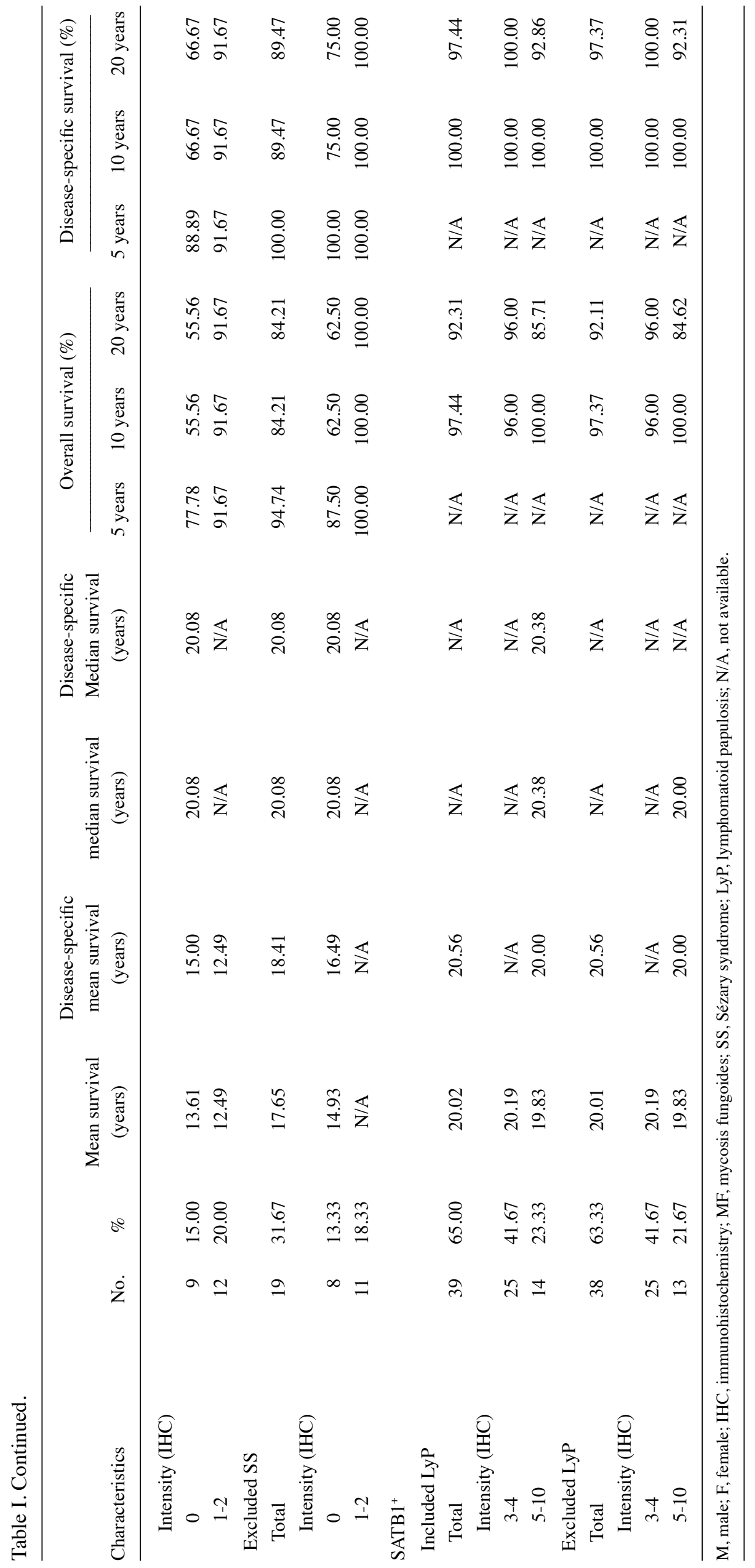


Table II. Analysis of demographic and clinical staging factors with regard to changes in overall and disease-specific survival.

\begin{tabular}{|c|c|c|c|c|c|c|c|c|c|c|}
\hline \multirow[b]{2}{*}{ Factors } & \multicolumn{5}{|c|}{ Overall survival } & \multicolumn{5}{|c|}{ Disease-specific survival } \\
\hline & HR & $95 \% \mathrm{CI}$ & $\mathrm{P}$-value $\mathrm{a}^{\mathrm{a}}$ & P-value ${ }^{b}$ & P-value & HR & $95 \% \mathrm{CI}$ & P-value ${ }^{a}$ & P-value ${ }^{b}$ & $\mathrm{P}$-value $\mathrm{c}^{\mathrm{c}}$ \\
\hline \multicolumn{11}{|l|}{ Age (years) } \\
\hline$<40$ & 1.00 & & & 0.8565 & 0.7915 & 1.00 & & & 0.3517 & 0.2226 \\
\hline $40-50$ & 0.59 & $0.06-5.72$ & & & & 0.59 & $0.06-5.72$ & & & \\
\hline $51-60$ & 0.61 & $0.06-5.91$ & & & & 1.19 & $0.07-19.24$ & & & \\
\hline$>60$ & 0.95 & $0.06-15.35$ & & & & 6.34 & $0.12-323.70$ & & & \\
\hline \multicolumn{11}{|l|}{ Gender } \\
\hline Male & 1.00 & & 0.1035 & 0.4172 & & 1.00 & & 0.2030 & 0.8876 & \\
\hline Female & 1.77 & $0.44-7.04$ & & & & 1.13 & $0.21-6.08$ & & & \\
\hline \multicolumn{11}{|c|}{ Disease subset } \\
\hline $\mathrm{MF}$ & 1.00 & & & $<0.0001$ & $<0.0001$ & 1.00 & & & $<0.0001$ & $<0.0001$ \\
\hline LyP & 2.78 & $0.25 \mathrm{E}-2-3020.00$ & & & & 2.774 & $0.13 \mathrm{E}-3-57323.00$ & & & \\
\hline SS & $0.29 \mathrm{E}-12$ & $0.15 \mathrm{E}-15-0.57 \mathrm{E}-9$ & & & & $0.12 \mathrm{E}-16$ & $0.18 \mathrm{E}-20-0.75 \mathrm{E}-13$ & & & \\
\hline \multicolumn{11}{|c|}{ T-classification } \\
\hline \multicolumn{11}{|c|}{ Simplified classification } \\
\hline $\mathrm{T} 1$ & 1.00 & & & 0.1089 & 0.0909 & 1.00 & & & 0.0192 & 0.0869 \\
\hline $\mathrm{T} 2$ & 1.06 & $0.19-5.84$ & & & & 4.47 & $0.39-51.21$ & & & \\
\hline $\mathrm{T} 4$ & 0.06 & $0.35 \mathrm{E}-2-0.91$ & & & & 0.04 & $0.24 \mathrm{E}-2-0.76$ & & & \\
\hline \multicolumn{11}{|c|}{ Extended classification } \\
\hline T1a & 1.00 & & & 0.1214 & 0.0991 & 1.00 & & & 0.0896 & 0.1688 \\
\hline $\mathrm{T} 1 \mathrm{~b}$ & 2.85 & $0.95 \mathrm{E}-2-847.90$ & & & & 2.86 & $0.34 \mathrm{E}-2-2368.00$ & & & \\
\hline $\mathrm{T} 2 \mathrm{a}$ & 1.92 & $0.29-12.68$ & & & & 4.36 & $0.36-52.13$ & & & \\
\hline $\mathrm{T} 2 \mathrm{~b}$ & 0.05 & $0.10 \mathrm{E}-2-2.68$ & & & & 2.90 & $0.84 \mathrm{E}-2-1000.00$ & & & \\
\hline $\mathrm{T} 4$ & 0.07 & $0.45 \mathrm{E}-2-1.036$ & & & & 0.05 & $0.32 \mathrm{E}-2-0.88$ & & & \\
\hline \multicolumn{11}{|l|}{ Progression } \\
\hline $\mathrm{T} 1 \mathrm{a}$ to $\mathrm{T} 2 \mathrm{a}$ & 1.00 & & & 0.8137 & 0.5064 & 1.00 & & & 0.78 & 0.4102 \\
\hline $\mathrm{T} 1 \mathrm{~b}$ to $\mathrm{T} 2 \mathrm{a}$ & 2.91 & $0.02-343.10$ & & & & 2.92 & $0.99 \mathrm{E}-2-859.00$ & & & \\
\hline $\mathrm{T} 2 \mathrm{a}$ to $\mathrm{T} 2 \mathrm{~b}$ & 2.86 & $0.01-591.00$ & & & & 2.85 & $0.35 \mathrm{E}-2-2342.00$ & & & \\
\hline $\mathrm{T} 2$ to $\mathrm{T} 3$ & 0.38 & $0.06-2.51$ & & & & 0.29 & $0.04-2.15$ & & & \\
\hline \multicolumn{11}{|c|}{ SATB1 expression (IHC) } \\
\hline \multicolumn{11}{|c|}{ Included LyP and SS } \\
\hline No & 1.00 & & 0.0033 & 0.0129 & & 1.00 & & 0.0033 & 0.0068 & \\
\hline Yes & 6.40 & $1.48-27.62$ & & & & 11.08 & $1.94-63.18$ & & & \\
\hline \multicolumn{11}{|c|}{ Excluded LyP and SS } \\
\hline No & 1.00 & & 0.0303 & 0.0857 & & 1.00 & & 0.0286 & 3.562 & \\
\hline Yes & 4.38 & $0.81-23.60$ & & & & 7.99 & $0.92-69.23$ & & & \\
\hline \multicolumn{11}{|c|}{ SATB1 intensity (IHC) } \\
\hline \multicolumn{11}{|c|}{ Included LyP and SS } \\
\hline 0 & 1.00 & & & 0.0260 & 0.0211 & 1.00 & & & 0.0276 & 0.0148 \\
\hline $1-2$ & 4.83 & $0.81-28.67$ & & & & 3.84 & $0.53-28.08$ & & & \\
\hline $3-4$ & 21.45 & $3.33-138.20$ & & & & 34.62 & $3.81-314.80$ & & & \\
\hline $5-10$ & 4.52 & $0.82-24.85$ & & & & 5.93 & $0.75-46.62$ & & & \\
\hline \multicolumn{11}{|c|}{ Excluded LyP and SS } \\
\hline 0 & 1.00 & & & 0.0695 & 0.0984 & 1.00 & & & 6.481 & 0.0897 \\
\hline $1-2$ & 9.80 & $1.00-96.07$ & & & & 9.37 & $0.58-152.40$ & & & \\
\hline $3-4$ & 18.42 & $2.36-143.50$ & & & & 32.07 & $2.52-408.10$ & & & \\
\hline $5-10$ & 3.593 & $0.5472-23.59$ & & & & 4.16 & $0.3841-45.01$ & & & \\
\hline
\end{tabular}

HR, hazard ratio; CI, confidence interval; IHC, immunohistochemistry; SS, Sézary syndrome; LyP, lymphomatoid papulosis. Bold, statistically significant differences. ${ }^{a}$ Gehan-Breslow-Wilcoxon test; ${ }^{b}$ Log-rank (Mantel-Cox) test; ${ }^{\circ} \log$-rank test for trend. 
Table III. Pairwise comparison of demographic and clinical staging factors with regard to changes in overall and disease-specific survival.

\begin{tabular}{|c|c|c|c|c|c|c|c|c|}
\hline \multirow[b]{2}{*}{ Factor } & \multicolumn{4}{|c|}{ Overall survival } & \multicolumn{4}{|c|}{ Disease-specific survival } \\
\hline & HR & $95 \% \mathrm{CI}$ & P-value ${ }^{a}$ & P-value ${ }^{b}$ & HR & $95 \% \mathrm{CI}$ & $\mathrm{P}$-value ${ }^{\mathrm{a}}$ & $\mathrm{P}$-value ${ }^{\mathrm{b}}$ \\
\hline \multicolumn{9}{|l|}{ Age (years) } \\
\hline$<40$ vs. $40-50$ & 0.59 & $0.06-5.72$ & 0.6723 & 0.6494 & 0.59 & $0.06-5.72$ & 0.6723 & 0.6494 \\
\hline$<40$ vs. $51-60$ & 0.61 & $0.06-5.91$ & 0.6939 & 0.6683 & 1.19 & $0.07-19.24$ & 0.9603 & 0.9037 \\
\hline$<40$ vs. $>60$ & 0.95 & $0.06-15.35$ & 0.9117 & 0.9738 & 6.34 & $0.12-323.70$ & 0.3576 & 0.3576 \\
\hline $40-50$ vs. $51-60$ & 1.58 & $0.27-9.11$ & 0.8621 & 0.6111 & 2.85 & $0.40-20.26$ & 0.5445 & 0.2951 \\
\hline $40-50$ vs. $>60$ & 2.35 & $0.36-15.35$ & 0.6453 & 0.3713 & 11.26 & $1.05-120.80$ & 0.1530 & 0.0456 \\
\hline $51-60$ vs. $>60$ & 1.17 & $0.15-9.20$ & 0.8359 & 0.8832 & 5.84 & $0.11-304.90$ & 0.3819 & 0.3819 \\
\hline \multicolumn{9}{|l|}{ T-classification } \\
\hline \multicolumn{9}{|l|}{ Simplified classification } \\
\hline T1 vs. T2 & 1.06 & $0.19-5.84$ & 0.9814 & 0.9461 & 4.47 & $0.39-51.21$ & 0.3408 & 0.2291 \\
\hline T1 vs. T4 & 0.06 & $0.35 \mathrm{E}-2-0.91$ & 0.0244 & 0.0426 & 0.04 & $0.24 \mathrm{E}-2-0.76$ & 0.0199 & 0.0319 \\
\hline T2 vs. T4 & 0.16 & $0.013-1.91$ & 0.1476 & 0.1467 & 0.03 & $0.16 \mathrm{E}-2-0.70$ & 0.0292 & 0.0288 \\
\hline \multicolumn{9}{|l|}{ Extended classification } \\
\hline T1a vs. T1b & 2.85 & $0.95 \mathrm{E}-2-847.9$ & 0.7194 & 0.7188 & 2.86 & $0.34 \mathrm{E}-2-2368$ & 0.7595 & 0.7592 \\
\hline T1a vs. T2a & 1.92 & $0.29-12.68$ & 0.3154 & 0.4996 & 4.36 & $0.36-52.13$ & 0.3640 & 0.2450 \\
\hline T1a vs. T2b & 0.05 & $0.10 \mathrm{E}-2-2.68$ & 0.0966 & 0.1422 & 2.90 & $0.84 \mathrm{E}-2-1000$ & 0.7216 & 0.7213 \\
\hline T1a vs. T4 & 0.07 & $0.45 \mathrm{E}-2-1.036$ & 0.0348 & 0.0531 & 0.05 & $0.32 \mathrm{E}-2-0.8804$ & 0.0287 & 0.0405 \\
\hline T1b vs. T2a & N/A & N/A & 1.0000 & 1.0000 & N/A & N/A & 1.0000 & 1.0000 \\
\hline T1b vs. T2b & 0.14 & $0.27 \mathrm{E}-2-6.82$ & 0.3173 & 0.3173 & N/A & N/A & 1.0000 & 1.0000 \\
\hline T1b vs. T4 & 0.23 & $0.01-4.55$ & 0.3367 & 0.3354 & 0.23 & $0.01-4.55$ & 0.3367 & 0.3354 \\
\hline T2a vs. T2b & $0.48 \mathrm{E}-2$ & $0.32 \mathrm{e}-4-0.73$ & 0.0374 & 0.0374 & N/A & N/A & 1.0000 & 1.0000 \\
\hline T2a vs. T4 & 0.05 & $0.26 \mathrm{E}-2-0.94$ & 0.0455 & 0.0451 & 0.05 & $0.26 \mathrm{E}-2-0.94$ & 0.0455 & 0.0451 \\
\hline T2b vs. T4 & 1.21 & $0.10-14.56$ & 0.8886 & 0.8822 & 0.25 & $0.01-5.61$ & 0.3841 & 0.383 \\
\hline \multicolumn{9}{|l|}{ Progression } \\
\hline T1a-T2a vs. T1b-T2a & 2.91 & $0.02-343.1$ & 0.6625 & 0.6609 & 2.92 & $0.99 \mathrm{E}-2-859.0$ & 0.7119 & 0.7114 \\
\hline T1a-T2a vs. T2a-T2b & 2.86 & $0.01-591.0$ & 0.7009 & 0.6995 & 2.85 & $0.35 \mathrm{E}-2-2342$ & 0.7604 & 0.7598 \\
\hline T1a-T2a vs. T2-T3 & 0.38 & $0.06-2.51$ & 0.2022 & 0.3152 & 0.29 & $0.04-2.15$ & 0.1370 & 0.2252 \\
\hline T1b-T2a vs. T2a-T2b & N/A & N/A & 1.0000 & 1.0000 & N/A & N/A & 1.0000 & 1.0000 \\
\hline T1b-T2a vs. T2-T3 & 0.28 & $0.90 \mathrm{E}-2-8.62$ & 0.4669 & 0.4658 & 0.28 & $0.90 \mathrm{E}-2-8.62$ & 0.4669 & 0.4658 \\
\hline T2a-T2b vs. T2-T3 & 0.31 & $0.66 \mathrm{E}-2-14.15$ & 0.5465 & 0.5449 & 0.31 & $0.66 \mathrm{E}-2-14.15$ & 0.5465 & 0.5449 \\
\hline \multicolumn{9}{|l|}{ SATB1 intensity (IHC) } \\
\hline \multicolumn{9}{|l|}{ Included LyP and SS } \\
\hline 0 vs. $1-2$ & 4.83 & $0.81-28.67$ & 0.0956 & 0.0830 & 3.84 & $0.53-28.08$ & 0.2222 & 0.1845 \\
\hline 0 vs. $3-4$ & 21.45 & $3.33-138.2$ & 0.0011 & 0.0013 & 34.62 & $3.81-314.8$ & 0.0017 & 0.0016 \\
\hline 0 vs. $5-10$ & 4.52 & $0.82-24.85$ & 0.0104 & 0.0827 & 5.93 & $0.75-46.62$ & 0.0236 & 0.0905 \\
\hline $1-2$ vs. $3-4$ & 3.64 & $0.15-89.46$ & 0.3203 & 0.4296 & 21.83 & $0.33-1437.00$ & 0.1489 & 0.1489 \\
\hline $1-2$ vs. $5-10$ & 8.73 & $0.17-445.10$ & 0.2801 & 0.2801 & 8.73 & $0.17-445.10$ & 0.2801 & 0.2801 \\
\hline $3-4$ vs. $5-10$ & 0.49 & $0.05-4.89$ & 0.5927 & 0.5435 & 0.14 & $0.27 \mathrm{E}-2-6.82$ & 0.3173 & 0.3173 \\
\hline \multicolumn{9}{|l|}{ Excluded LyP and SS } \\
\hline 0 vs. $1-2$ & 9.80 & $1.00-96.07$ & 0.0513 & 0.0499 & 9.37 & $0.58-152.40$ & 0.1167 & 0.1159 \\
\hline 0 vs. $3-4$ & 18.42 & $2.36-143.50$ & 0.0050 & 0.0054 & 32.07 & $2.52-408.10$ & 0.0068 & 0.0075 \\
\hline 0 vs. $5-10$ & 3.59 & $0.55-23.59$ & 0.0246 & 0.1829 & 4.16 & $0.38-45.01$ & 0.0673 & 0.2410 \\
\hline $1-2$ vs. $3-4$ & 0.29 & $0.20 \mathrm{E}-2-41.89$ & 0.6256 & 0.6256 & N/A & N/A & 1.0000 & 1.0000 \\
\hline $1-2$ vs. $5-10$ & N/A & N/A & 1.0000 & 1.0000 & N/A & N/A & 1.0000 & 1.0000 \\
\hline $3-4$ vs. $5-10$ & 0.50 & $0.05-4.96$ & 0.5839 & 0.5533 & 0.14 & $0.27 \mathrm{E}-2-6.82$ & 0.3173 & 0.3173 \\
\hline
\end{tabular}

HR, hazard ratio; CI, confidence interval; IHC, immunohistochemistry; SS, Sézary syndrome; LyP, lymphomatoid papulosis; N/A, not available. Bold, statistically significant differences. ${ }^{\mathrm{a} G e h a n-B r e s l o w-W i l c o x o n}$ test; ${ }^{\mathrm{b}} \mathrm{Log}$-rank (Mantel-Cox) test. 

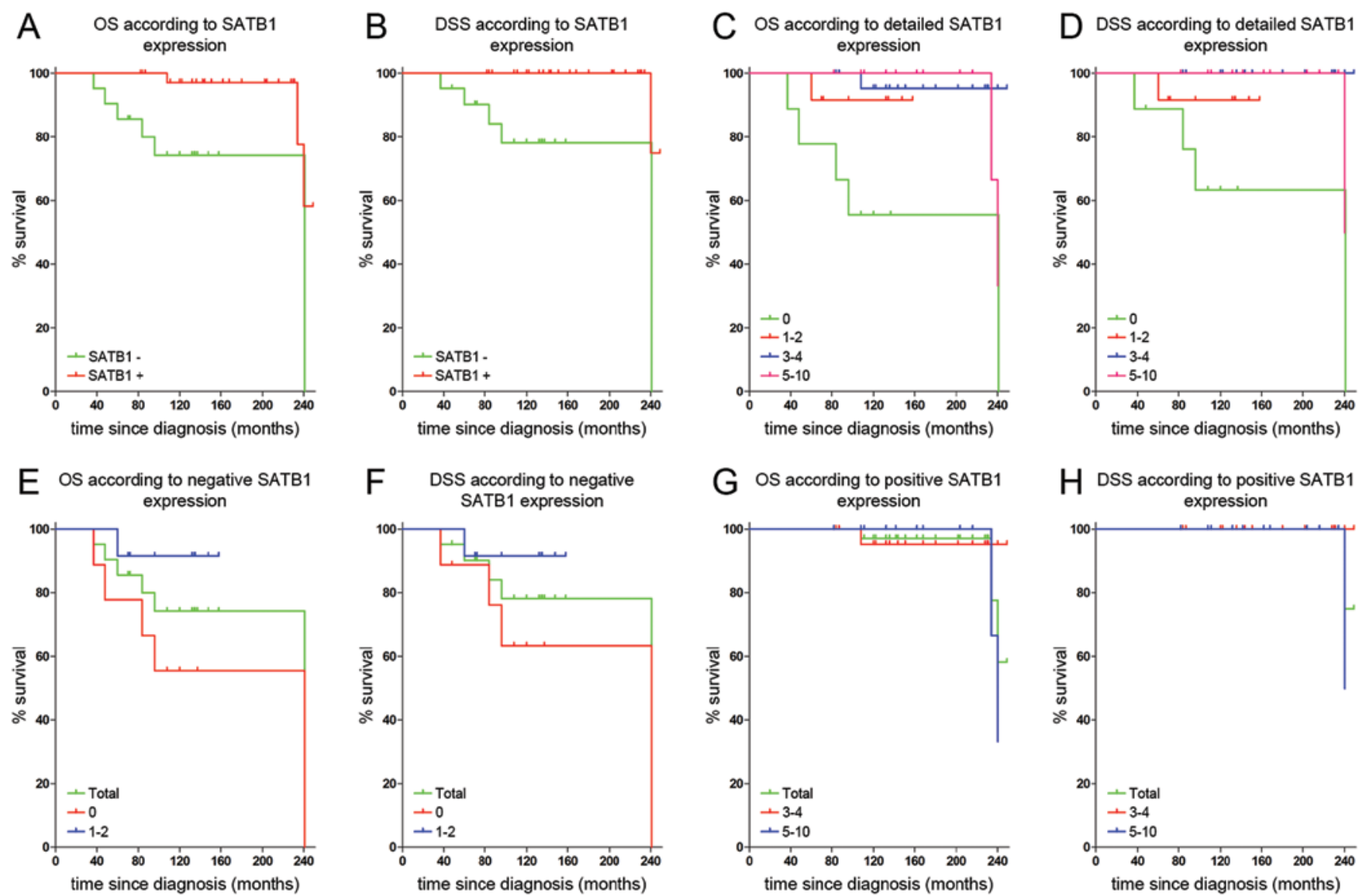

Figure 3. Kaplan-Meier analysis of overall survival (OS) and disease-specific survival (DSS) by special AT-rich sequence-binding protein-1 (SATB1) expression. (A) OS by positive and negative SATB1 expression. (B) DSS by positive and negative SATB1 expression. (C) OS by numerical SATB1 expression. (D) DSS by numerical SATB1 expression. (E) OS by numerical SATB1 expression (negative). (F) DSS by numerical SATB1 expression (negative). (G) OS by numerical SATB1 expression (positive). (H) DSS by numerical SATB1 expression (positive).

labeling (Table III). Exclusion of SS and LyP showed similar results; however, statistically significant differences in distribution of survival curve were observed after comparison of groups of patients that were characterized as SATB1-negative (HR=9.80, $\mathrm{P}=0.0499)$. According to pairwise comparison of DSS after exclusion of SS and LyP, statistically significant changes in the likelihood of survival were observed only when comparing patients with moderate expression of SATB1 to patients without any SATB1 labeling $(\mathrm{HR}=32.07, \mathrm{P}=0.0068$; Table III).

Risk of disease progression by demographic factors, disease subset and T-classification. Disease progression was noted in $50 \%$ (without T1a to T1b and T2a to T2b) or $51.67 \%$ (with T1a to T1b and T2a to T2b), and is shown in Tables IV-VI, with Kaplan-Meier time-to-event curves in Fig. 4. Risk of disease progression (RDP) was considered in patients divided according to age, gender, disease subset as well as T-classification. The analysis of total patients showed that RDP increased with time and independently of T1a to T1b and T2a to T2b progression (1.67\% for 5 years RDP, $21.67 \%$ for 10 years RDP, and 48.33 or $50 \%$ for 20 years RDP without and with T1a to T1b and T2a to T2b, respectively; Table IV).

According to the age at the time of diagnosis, the highest 20-year RDP was observed in patients at the age range of
51-60 years $(58.82 \%)$, whereas the lowest was in patients classified in the group aged 40-50 years (37.50\%) (Table IV). However, pairwise comparison of age groups did not show statistically significant changes (Table VI). Similarly, analysis of RDP, both without and with progression from T1a to Tlb and $\mathrm{T} 2 \mathrm{a}$ to $\mathrm{T} 2 \mathrm{~b}$, showed higher risk in women $(4.76 \%$ for 10 years RDP and 16.67 or $19.05 \%$ for 20 years RDP, respectively) than in men (16.67\% for 10 years RDP and $44.44 \%$ for 20 years RDP) but was not statistically significant (Table IV).

Pairwise comparison showed statistically significant lower risk of progression for patients diagnosed in both LyP and SS (HR=7.6 $6^{-3}$ and HR=5.4 ${ }^{-13}$, respectively), as compared to $\mathrm{MF}(\mathrm{P}<0.0001)$. Moreover, analysis of patients grouped according to T-classification showed the highest 20 -year RDP in patients diagnosed at T2 (75\% for RDP both without or with progression from $\mathrm{T} 1 \mathrm{a}$ to $\mathrm{T} 1 \mathrm{~b}$ and $\mathrm{T} 2 \mathrm{a}$ to $\mathrm{T} 2 \mathrm{~b}$ ) and the lowest at T1 stage (37.84 or $40.54 \%$ for RDP without or with progression from $\mathrm{T} 1 \mathrm{a}$ to $\mathrm{T} 1 \mathrm{~b}$ and $\mathrm{T} 2 \mathrm{a}$ to $\mathrm{T} 2 \mathrm{~b}$, respectively; Table IV). Furthermore, analysis of trend showed a statistically significant decrease of RDP calculated without or with T1a to T1b and T2a to T2b progression ( $\mathrm{HR}=0.48$ for $\mathrm{T} 2$ and $\mathrm{HR}=0.08$ for $\mathrm{T} 4, \mathrm{P}=0.0157$ or $\mathrm{HR}=0.52$ for $\mathrm{T} 2$ and $\mathrm{HR}=0.10$ for $\mathrm{T} 4, \mathrm{P}=0.0224$, respectively; Table V). However, pairwise comparison revealed statistically significant changes between $\mathrm{T} 1$ and $\mathrm{T} 4$ stages $(\mathrm{HR}=0.08, \mathrm{P}=0.0125$ or $\mathrm{HR}=0.10$, 


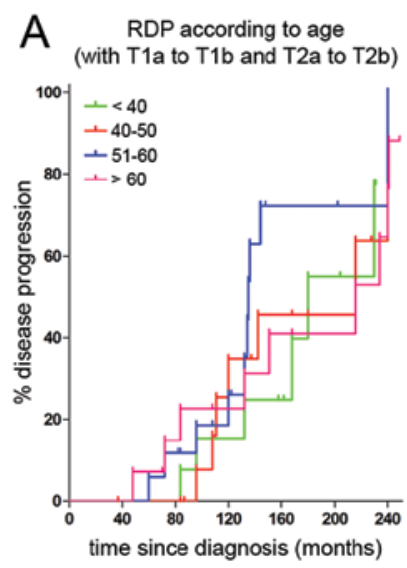

E RDP according to disease subset (with $\mathrm{T} 1 \mathrm{a}$ to $\mathrm{T} 1 \mathrm{~b}$ and $\mathrm{T} 2 \mathrm{a}$ to $\mathrm{T} 2 \mathrm{~b}$ )

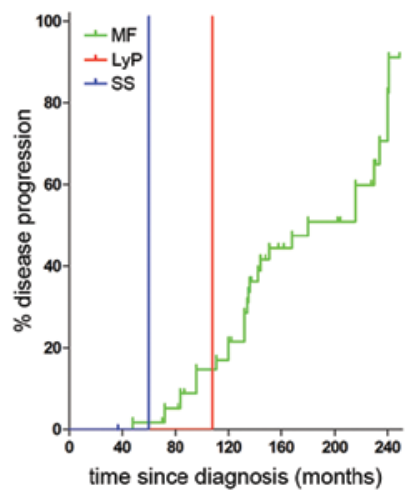

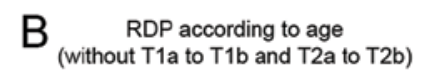

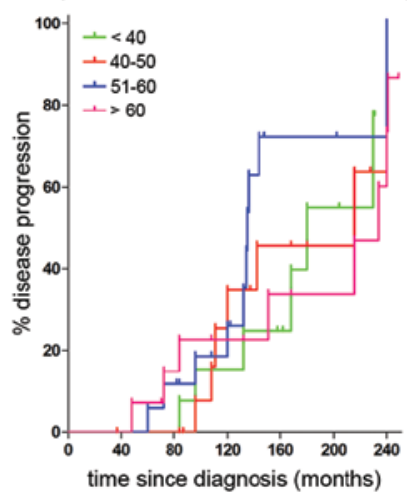

F RDP according to disease subset (without T1a to T1b and T2a to T2b)

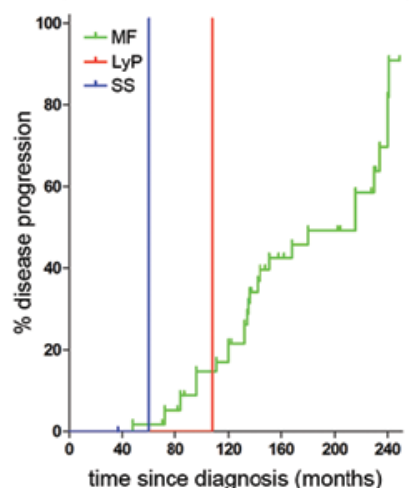

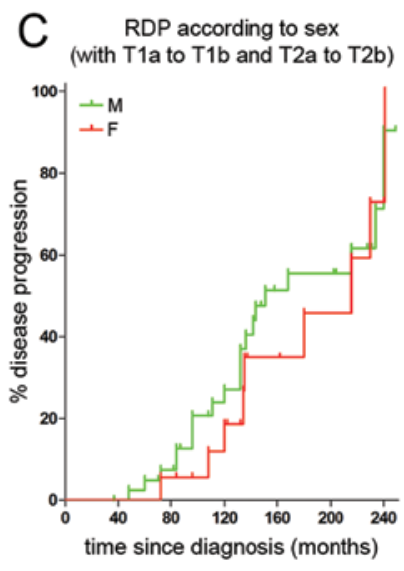

$G$ RDP according to $T$ classification (with $\mathrm{T} 1 \mathrm{a}$ to $\mathrm{T} 1 \mathrm{~b}$ and $\mathrm{T} 2 \mathrm{a}$ to $\mathrm{T} 2 \mathrm{~b}$ )

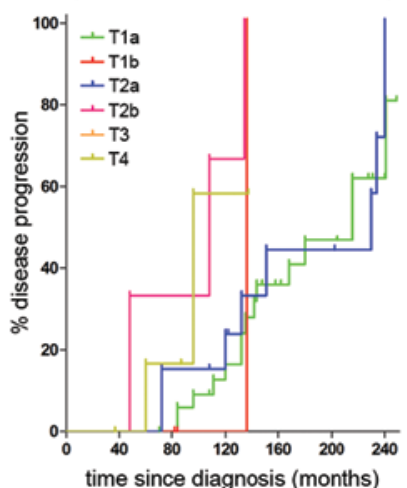

D RDP according to sex (without T1a to T1b and T2a to T2b)

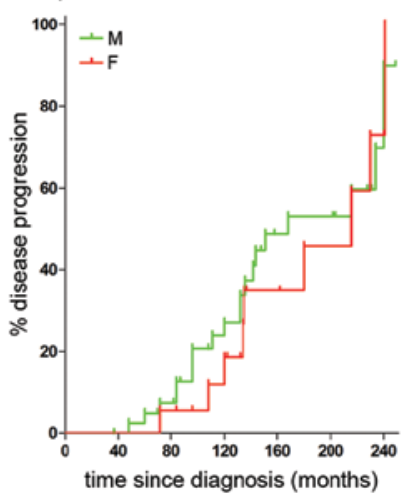

H RDP according to T classification (without T1a to T1b and T2a to T2b)

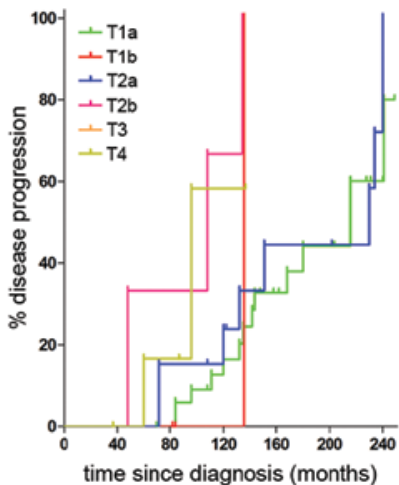

Figure 4. Kaplan-Meier analysis of risk of disease progression (RDP) by age, gender, disease subset and T-classification. (A) RDP with T1a to T1b and T2a to T2b by age. (B) RDP without T1a to T1b and T2a to T2b by age. (C) RDP with T1a to T1b and T2a to T2b by gender. (D) RDP without T1a to T1b and T2a to T2b by gender. (E) RDP with T1a to T1b and T2a to T2b by disease subset. (F) RDP without T1a to T1b and T2a to T2b by disease subset. (G) RDP with T1a to T1b and T2a to T2b by T-classification. (H) RDP without T1a to T1b and T2a to T2b by T-classification.

$\mathrm{P}=0.0146$ for RDP without or with progression from T1a to T1b and T2a to T2b, respectively; Table VI). Similarly, comparison of RDP according to extended T-classification showed statistically significant decrease with stage $(\mathrm{P}=0.0042$ or $\mathrm{P}=0.0072$; Table $\mathrm{V}$ ). However, pairwise analysis showed statistically significant differences between patients diagnosed at $\mathrm{T} 1 \mathrm{a}$ and $\mathrm{T} 2 \mathrm{~b}\left(\mathrm{HR}=4.6^{-3}, \mathrm{P}=0.0006\right.$ or $\mathrm{HR}=7.5^{-3}, \mathrm{P}=0.0009$, respectively), $\mathrm{T} 1 \mathrm{a}$ and $\mathrm{T} 4(\mathrm{HR}=0.08, \mathrm{P}=0.0138$ or $\mathrm{HR}=0.09$, $\mathrm{P}=0.0162$, respectively), as well as between patients diagnosed at $\mathrm{T} 2 \mathrm{a}$ and $\mathrm{T} 2 \mathrm{~b}(\mathrm{HR}=0.08, \mathrm{P}=0.0376)($ Table VI $)$.

Risk of disease progression by SATB1 expression. Disease progression was also analyzed according to SATB1 expression and is shown in Tables III-VI, with Kaplan-Meier time-to-event curves in Fig. 5. According to patients grouped as SATB1-negative, the 20-year RDP was higher in patients characterized without any SATB1 labeling $(55.56 \%)$ than in patients with low SATB1 expression (50\%). Additionally, SATB1-positive patients were characterized by lower 20-year RDP $(46.15 \%)$, as compared to SATB-negative patients $(52.38 \%)$. Furthermore, analysis of trend showed a statistically significant increase of RDP calculated without or with T1a to $\mathrm{T} 1 \mathrm{~b}$ and $\mathrm{T} 2 \mathrm{a}$ to $\mathrm{T} 2 \mathrm{~b}$ progression in SATB1-positive patients ( $\mathrm{HR}=3.39, \mathrm{P}=0.0005$ or $\mathrm{HR}=3.85, \mathrm{P}=0.0002$, respectively), even if SS and LyP were excluded from experimental groups $(\mathrm{HR}=3.35, \mathrm{P}=0.0008$ or $\mathrm{HR}=3.86, \mathrm{P}=0.0003$, respectively;
Table V). However, pairwise comparison revealed statistically significant changes between patients without SATB1 labeling and its moderate expression $(\mathrm{HR}=3.22, \mathrm{P}=0.0051)$, without SATB1 labeling and its high expression $(\mathrm{HR}=2.54, \mathrm{P}=0.0196)$, low and moderate SATB1 expression $(\mathrm{HR}=4.14, \mathrm{P}=0.0165$ or $\mathrm{HR}=5.23, \mathrm{P}=0.0064)$, as well as between low and high SATB1 expression $(\mathrm{HR}=4.86, \mathrm{P}=0.0255$ or $\mathrm{HR}=5.72, \mathrm{P}=0.0110)$. Similar results were obtained following HR analysis without SS and LyP patients (Table VI).

It is also of note that SATB1-positive patients stayed longer in each $\mathrm{T}$ stage (8.64 years in $\mathrm{T} 1,8.36$ years in $\mathrm{T} 2$, 3.5 years in $\mathrm{T} 3$, and 7.25 years in $\mathrm{T} 4$ ) than SATB1-negative patients (4.58 years in T1, 5.67 years in T2, 2.08 years in T3. and 7.25 years in T4), which correlated with enhanced survival of these patients.

Apoptosis induction in Jurkat cells with downregulated SATB1. To investigate the possible mechanism by which patients deficient in SATB1 or characterized by low SATB1 expression have poorer prognosis, we subjected downregulated Jurkat cells to apoptosis analysis after activation with CD3 mAb, CD95 mAb and PMA/Io after a 3-day stimulation with IL-2 (Fig. 6). The results showed that downregulation of SATB1 using siRNA caused statistically significant resistance to activation-induced cell death (AICD) in Jurkat cells, in all cases of treatment (from 49.22 to $25.07 \%, \mathrm{P}=0.0294$; from 

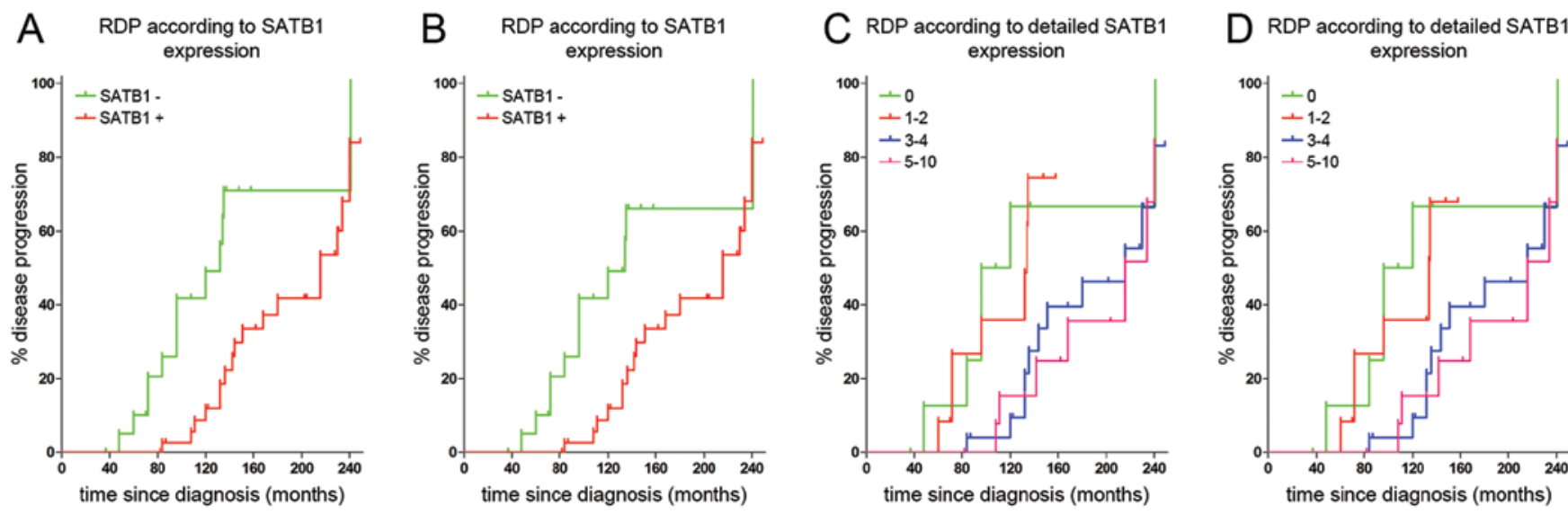

\section{E RDP according to negative}
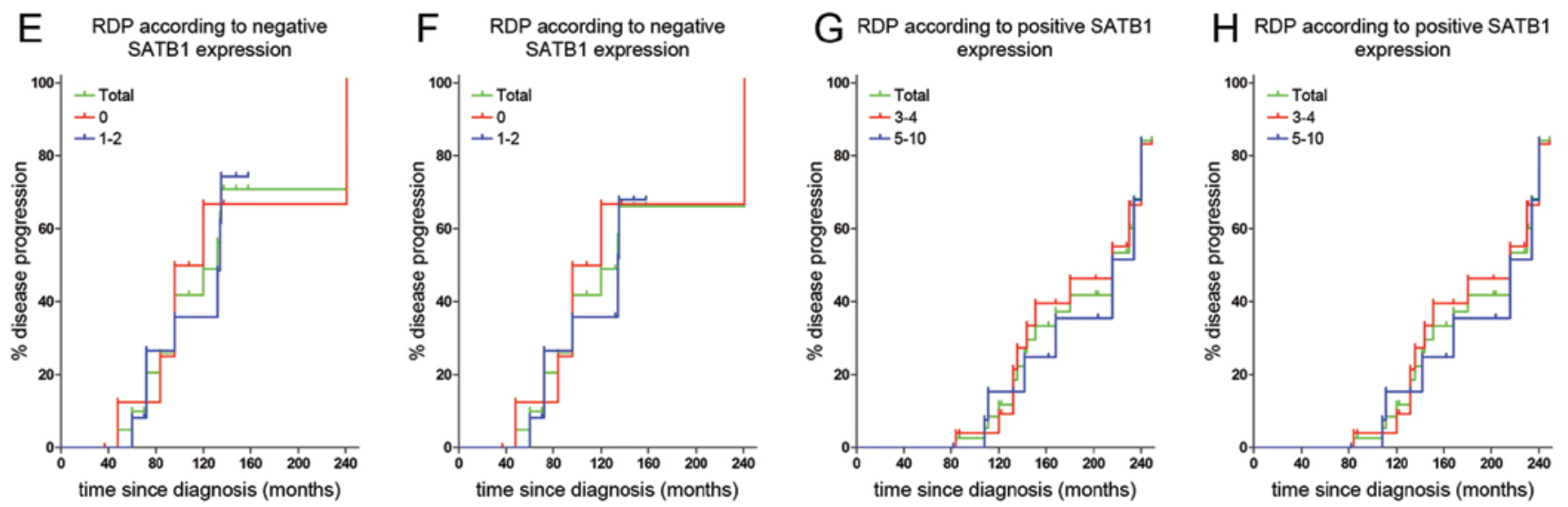

Figure 5. Kaplan-Meier analysis of risk of disease progression (RDP) by special AT-rich sequence-binding protein-1 (SATB1) expression. (A) RDP with T1a to T1b and T2a to T2b by positive and negative SATB1 expression. (B) RDP without T1a to T1b and T2a to T2b by positive and negative SATB1 expression. (C) RDP with T1a to T1b and T2a to T2b by numerical SATB1 expression. (D) RDP without T1a to T1b and T2a to T2b by numerical SATB1 expression. (E) RDP with T1a to T1b and T2a to T2b by numerical SATB1 expression (negative). (F) RDP without T1a to T1b and T2a to T2b by numerical SATB1 expression (negative). (G) RDP with T1a to T1b and T2a to T2b by numerical SATB1 expression (positive). (H) RDP without T1a to T1b and T2a to T2b by numerical SATB1 expression (positive).
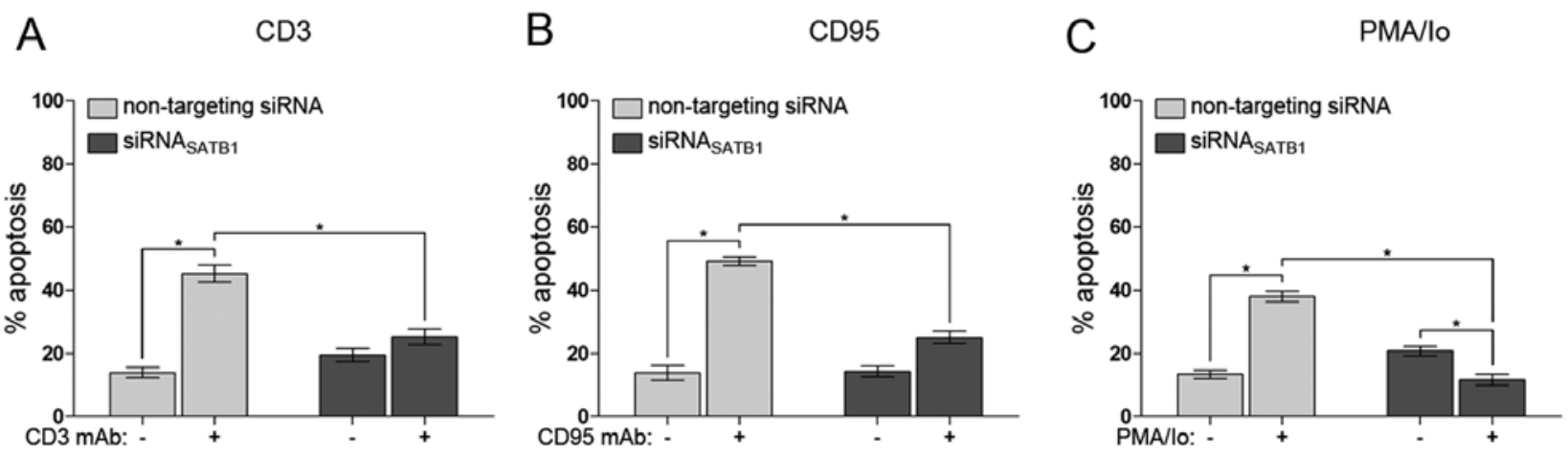

Figure 6. Effect of downregulation of special AT-rich sequence-binding protein-1 (SATB1) on activation-induced cell death in Jurkat cells. (A) Percentage of apoptotic cells after $16 \mathrm{~h}$ culture on $10 \mu \mathrm{g} / \mathrm{ml}$ UCHT-1 CD3 monoclonal antibody-coated plates. (B) Percentage of apoptotic cells after 16-h treatment with $2.5 \mu \mathrm{g} / 50 \mu \mathrm{lDX} 2 \mathrm{CD} 95$ monoclonal antibody. (C) Percentage of apoptotic cells after a 3-day culture in the presence of $10 \mathrm{ng} / \mathrm{ml}$ recombinant human IL-2 and 16 -h treatment with $100 \mathrm{ng} / \mathrm{ml}$ phorbol 12-myristate 13 -acetate and $1 \mu \mathrm{g} / \mathrm{ml}$ ionomycin.

45.27 to $25.28, \mathrm{P}=0.0159$; and from 38.03 to $11.67 \%, \mathrm{P}=0.0357$; after treatment of cells transfected with non-targeting siRNA and siRNA ${ }_{\mathrm{SATB} 1}$ with CD3 mAb, CD95 mAb and PMA/Io, respectively). Moreover, the analysis did not show any statistically significant differences between appropriate controls (cells transfected with non-targeting siRNA and siRNA ${ }_{\mathrm{SATB1}}$ ).

\section{Discussion}

MF is a type of epidermotropic primary CTCL characterized by a slow clinical course and proliferation of small and medium-sized T lymphocytes with cerebriform nuclei (26-29). MF is the most common form of CTCL and accounts for 
Table IV. Summary of demographic and clinical staging characteristics according to ISCL/EORTC classification.

\begin{tabular}{|c|c|c|c|c|c|c|c|c|}
\hline \multirow[b]{2}{*}{ Characteristics } & \multirow[b]{2}{*}{ No } & \multirow[b]{2}{*}{$\%$} & \multicolumn{3}{|c|}{$\begin{array}{c}\text { Risk of disease progression } \\
\text { w/o T1a to T1b and T2a-T2b (\%) }\end{array}$} & \multicolumn{3}{|c|}{$\begin{array}{c}\text { Risk of disease progression } \\
\text { with T1a to T1b and T2a-T2b (\%) }\end{array}$} \\
\hline & & & 5 years & 10 years & 20 years & 5 years & 10 years & 20 years \\
\hline Total patients & 60 & & 1.67 & 21.67 & 48.33 & 1.67 & 21.67 & 50.00 \\
\hline \multicolumn{9}{|l|}{ Age (years) } \\
\hline$<40$ & 13 & 21.67 & N/A & 15.38 & 46.15 & N/A & 15.38 & 46.15 \\
\hline $40-50$ & 16 & 26.67 & 0.00 & 25.00 & 37.50 & 0.00 & 25.00 & 37.50 \\
\hline $51-60$ & 17 & 28.33 & 5.88 & 23.53 & 58.82 & 5.88 & 23.53 & 58.82 \\
\hline$>60$ & 14 & 23.33 & 7.14 & 21.43 & 50.00 & 7.14 & 21.43 & 57.14 \\
\hline \multicolumn{9}{|l|}{ Gender } \\
\hline Male & 42 & 70.00 & 4.76 & 4.76 & 16.67 & 4.76 & 7.14 & 19.05 \\
\hline Female & 18 & 30.00 & N/A & 16.67 & 44.44 & N/A & 16.67 & 44.44 \\
\hline \multicolumn{9}{|l|}{ Disease subset } \\
\hline MF & 57 & 95.00 & 1.75 & 19.30 & 47.37 & 1.75 & 19.30 & 49.12 \\
\hline LyP & 1 & 1.67 & N/A & 100.00 & N/A & N/A & 100.00 & N/A \\
\hline SS & 2 & 3.33 & 0.00 & 50.00 & N/A & 0.00 & 50.00 & N/A \\
\hline \multicolumn{9}{|c|}{ Clinical/histologic variants } \\
\hline MF & 56 & 93.33 & 1.79 & 19.64 & 46.43 & 1.79 & 19.64 & 48.21 \\
\hline Foll. MF & 1 & 1.67 & N/A & N/A & 100.00 & N/A & N/A & 100.00 \\
\hline \multicolumn{9}{|l|}{ T-classification } \\
\hline \multicolumn{9}{|l|}{$\mathrm{T} 1$} \\
\hline Total & 37 & 61.67 & N/A & 13.51 & 37.84 & N/A & 13.51 & 40.54 \\
\hline T1a & 34 & 56.67 & N/A & 14.71 & 38.24 & N/A & 14.71 & 41.18 \\
\hline $\mathrm{T} 1 \mathrm{~b}$ & 3 & 5.00 & N/A & 0.00 & 33.33 & $\mathrm{~N} / \mathrm{A}$ & 0.00 & 33.33 \\
\hline \multicolumn{9}{|l|}{$\mathrm{T} 2$} \\
\hline Total & 16 & 26.67 & 6.25 & 31.25 & 75.00 & 6.25 & 31.25 & 75.00 \\
\hline $\mathrm{T} 2 \mathrm{a}$ & 13 & 21.67 & N/A & 23.08 & 69.23 & $\mathrm{~N} / \mathrm{A}$ & 23.08 & 69.23 \\
\hline $\mathrm{T} 2 \mathrm{~b}$ & 3 & 5.00 & 33.33 & 33.33 & 33.33 & 33.33 & 33.33 & 33.33 \\
\hline $\mathrm{T} 3$ & 0 & 0.00 & N/A & N/A & N/A & N/A & N/A & N/A \\
\hline $\mathrm{T} 4$ & 7 & 11.67 & 14.29 & 42.86 & 42.86 & 14.29 & 42.86 & 42.86 \\
\hline \multicolumn{9}{|l|}{ SATB1- } \\
\hline \multicolumn{9}{|l|}{ Included SS } \\
\hline \multicolumn{8}{|c|}{ Intensity (IHC) } & 57.14 \\
\hline 0 & 9 & 15.00 & 11.11 & 55.56 & 55.56 & 11.11 & 55.56 & 55.56 \\
\hline $1-2$ & 12 & 20.00 & 8.33 & 33.33 & 50.00 & 8.33 & 33.33 & 58.33 \\
\hline \multicolumn{9}{|l|}{ Excluded SS } \\
\hline \multicolumn{9}{|c|}{ Intensity (IHC) } \\
\hline 0 & 8 & 13.33 & 12.50 & 62.50 & 62.50 & 12.50 & 62.50 & 62.50 \\
\hline $1-2$ & 11 & 18.33 & 0.00 & 27.27 & 45.45 & 0.00 & 27.27 & 54.55 \\
\hline \multicolumn{9}{|l|}{ SATB $1^{+}$} \\
\hline \multicolumn{9}{|l|}{ Included LyP } \\
\hline $\begin{array}{l}\text { Total } \\
\text { Intensity (IH }\end{array}$ & 39 & 65.00 & N/A & 10.26 & 46.15 & N/A & 10.26 & 46.15 \\
\hline $3-4$ & 25 & 41.67 & N/A & 8.00 & 44.00 & N/A & 8.00 & 44.00 \\
\hline $5-10$ & 14 & 23.33 & N/A & 0.00 & 50.00 & N/A & 0.00 & 50.00 \\
\hline \multicolumn{9}{|l|}{ Excluded LyP } \\
\hline $\begin{array}{l}\text { Total } \\
\text { Intensity (IH }\end{array}$ & 38 & 63.33 & N/A & 7.89 & 44.74 & N/A & 7.89 & 44.74 \\
\hline $3-4$ & 25 & 41.67 & N/A & 8.00 & 44.00 & N/A & 8.00 & 44.00 \\
\hline $5-10$ & 13 & 21.67 & N/A & 0.00 & 46.15 & N/A & 0.00 & 46.15 \\
\hline
\end{tabular}

IHC, immunohistochemistry; MF, mycosis fungoides; SS, Sézary syndrome; LyP, lymphomatoid papulosis. N/A, not available. 
Table V. Analysis of demographic and clinical staging factors with regard to changes in risk of disease progression.

\begin{tabular}{|c|c|c|c|c|c|c|c|c|c|c|}
\hline \multirow[b]{2}{*}{ Factors } & \multicolumn{5}{|c|}{ Risk of disease progression w/o $\mathrm{T} 1 \mathrm{a}$ to $\mathrm{T} 1 \mathrm{~b}$ and $\mathrm{T} 2 \mathrm{a}$ to $\mathrm{T} 2 \mathrm{~b}$} & \multicolumn{5}{|c|}{ Risk of disease progression with $\mathrm{T} 1 \mathrm{a}$ to $\mathrm{T} 1 \mathrm{~b}$ and $\mathrm{T} 2 \mathrm{a}$ to $\mathrm{T} 2 \mathrm{~b}$} \\
\hline & HR & $95 \% \mathrm{CI}$ & P-value ${ }^{a}$ & P-value ${ }^{b}$ & P-value ${ }^{c}$ & HR & $95 \% \mathrm{CI}$ & P-value ${ }^{a}$ & $\mathrm{P}$-value ${ }^{\mathrm{b}}$ & $\mathrm{P}$-value $\mathrm{c}^{\mathrm{c}}$ \\
\hline \multicolumn{11}{|l|}{ Age (years) } \\
\hline$<40$ & 1.00 & & & 0.4388 & 0.9992 & 1.00 & & & 0.5252 & 0.8179 \\
\hline $40-50$ & 0.97 & $0.31-3.04$ & & & & 0.97 & $0.31-3.04$ & & & \\
\hline $51-60$ & 0.55 & $0.19-1.55$ & & & & 0.55 & $0.19-1.55$ & & & \\
\hline$>60$ & 1.38 & $0.41-4.61$ & & & & 1.13 & $0.35-3.60$ & & & \\
\hline \multicolumn{11}{|l|}{ Gender } \\
\hline Male & 1.00 & & 0.3744 & 0.5946 & & 1.00 & & 0.3192 & 0.5136 & \\
\hline Female & 1.23 & $0.57-2.66$ & & & & 1.29 & $0.60-2.75$ & & & \\
\hline \multicolumn{11}{|c|}{ Disease subset } \\
\hline MF & 1.00 & & & $<0.0001$ & $<0.0001$ & 1.00 & & & $<0.0001$ & $<0.0001$ \\
\hline LyP & $0.76 \mathrm{E}-2$ & $0.65 \mathrm{E}-4-0.90$ & & & & $0.76 \mathrm{E}-2$ & $0.65 \mathrm{E}-4-0.90$ & & & \\
\hline SS & $0.54 \mathrm{E}-12$ & $0.13 \mathrm{E}-16-0.22 \mathrm{E}-7$ & & & & $0.54 \mathrm{E}-12$ & $0.13 \mathrm{E}-16-0.22 \mathrm{E}-7$ & & & \\
\hline \multicolumn{11}{|c|}{ T-classification } \\
\hline \multicolumn{11}{|c|}{ Simplified classification } \\
\hline $\mathrm{T} 1$ & 1.00 & & & 0.0541 & 0.0157 & 1.00 & & & 0.0732 & 0.0224 \\
\hline $\mathrm{T} 2$ & 0.48 & $0.21-1.14$ & & & & 0.52 & $0.22-1.21$ & & & \\
\hline $\mathrm{T} 4$ & 0.08 & $0.96 \mathrm{E}-2-0.72$ & & & & 0.10 & $0.01-0.80$ & & & \\
\hline \multicolumn{11}{|c|}{ Extended classification } \\
\hline T1a & 1.00 & & & 0.0042 & 0.0057 & 1.00 & & & 0.0072 & 0.0090 \\
\hline $\mathrm{T} 1 \mathrm{~b}$ & 0.17 & $0.60 \mathrm{E}-2-4.55$ & & & & 0.22 & $0.95 \mathrm{E}-2-5.14$ & & & \\
\hline $\mathrm{T} 2 \mathrm{a}$ & 0.62 & $0.24-1.58$ & & & & 0.67 & $0.27-1.68$ & & & \\
\hline $\mathrm{T} 2 \mathrm{~b}$ & $0.46 \mathrm{E}-2$ & $0.26 \mathrm{E}-3-0.08$ & & & & $0.75 \mathrm{E}-2$ & $0.47 \mathrm{E}-3-0.12$ & & & \\
\hline $\mathrm{T} 4$ & 0.08 & $0.88 \mathrm{E}-2-0.69$ & & & & 0.09 & $0.01-0.77$ & & & \\
\hline \multicolumn{11}{|l|}{ Progression } \\
\hline $\mathrm{T} 1 \mathrm{a}$ to $\mathrm{T} 2 \mathrm{a}$ & 1.00 & & & 0.7314 & 0.9971 & 1.00 & & & 0.8041 & 0.9056 \\
\hline $\mathrm{T} 1 \mathrm{~b}$ to $\mathrm{T} 2 \mathrm{a}$ & 0.14 & $0.44 \mathrm{E}-2-4.29$ & & & & 0.22 & $0.92 \mathrm{E}-2-5.20$ & & & \\
\hline $\mathrm{T} 2 \mathrm{a}$ to $\mathrm{T} 2 \mathrm{~b}$ & 0.72 & $0.06-7.97$ & & & & 0.80 & $0.08-8.08$ & & & \\
\hline $\mathrm{T} 2$ to $\mathrm{T} 3$ & 1.00 & $0.20-5.00$ & & & & 1.11 & $0.24-5.17$ & & & \\
\hline \multicolumn{11}{|c|}{ SATB1 expression (IHC) } \\
\hline \multicolumn{11}{|c|}{ Included LyP and SS } \\
\hline No & 1.00 & & 0.0005 & 0.0089 & & 1.00 & & 0.0002 & 0.0033 & \\
\hline Yes & 3.39 & $1.36-8.45$ & & & & 3.85 & $1.57-9.48$ & & & \\
\hline \multicolumn{11}{|c|}{ Excluded LyP and SS } \\
\hline No & 1.00 & & 0.0008 & 0.0129 & & 1.00 & & 0.0003 & 0.0048 & \\
\hline Yes & 3.35 & $1.29-8.70$ & & & & 3.86 & $1.51-9.85$ & & & \\
\hline \multicolumn{11}{|c|}{ SATB1 intensity (IHC) } \\
\hline \multicolumn{11}{|c|}{ Included LyP and SS } \\
\hline 0 & 1.00 & & & 0.0935 & 0.0391 & 1.00 & & & 0.0386 & 0.0251 \\
\hline $1-2$ & 1.25 & $0.36-4.31$ & & & & 1.10 & $0.33-3.63$ & & & \\
\hline $3-4$ & 3.22 & $0.90-11.46$ & & & & 3.22 & $0.90-11.46$ & & & \\
\hline $5-10$ & 2.54 & $0.66-9.68$ & & & & 2.54 & $0.66-9.68$ & & & \\
\hline \multicolumn{11}{|c|}{ Excluded LyP and SS } \\
\hline 0 & 1.00 & & & 0.1261 & 0.0321 & 1.00 & & & 0.0574 & 0.0202 \\
\hline $1-2$ & 1.48 & $0.40-5.46$ & & & & 1.28 & $0.37-4.45$ & & & \\
\hline $3-4$ & 3.22 & $0.90-11.46$ & & & & 3.22 & $0.90-11.46$ & & & \\
\hline $5-10$ & 2.97 & $0.74-11.95$ & & & & 2.97 & $0.74-11.95$ & & & \\
\hline
\end{tabular}

HR, hazard ratio; CI, confidence interval; IHC, immunohistochemistry; SS, Sézary syndrome; LyP, lymphomatoid papulosis. Bold, statistically significant differences. ${ }^{a}$ Gehan-Breslow-Wilcoxon test; ${ }^{b} \log$-rank (Mantel-Cox) test; ${ }^{c} \log$-rank test for trend. 
Table VI. Pairwise comparison of demographic and clinical staging factors with regard to changes in risk of disease progression.

\begin{tabular}{|c|c|c|c|c|c|c|c|c|}
\hline \multirow[b]{2}{*}{ Factors } & \multicolumn{4}{|c|}{$\begin{array}{l}\text { Risk of disease progression } \\
\text { w/o T1a to T1b and T2a to T2b }\end{array}$} & \multicolumn{4}{|c|}{$\begin{array}{l}\text { Risk of disease progression } \\
\text { with T1a to T1b and T2a to T2b }\end{array}$} \\
\hline & HR & $95 \% \mathrm{CI}$ & $\mathrm{P}$-value ${ }^{\mathrm{a}}$ & $\mathrm{P}$-value ${ }^{\mathrm{b}}$ & HR & $95 \% \mathrm{CI}$ & P-value ${ }^{a}$ & $\mathrm{P}$-value ${ }^{\mathrm{b}}$ \\
\hline \multicolumn{9}{|l|}{ Age (years) } \\
\hline$<40$ vs. $40-50$ & 0.97 & $0.31-3.04$ & 0.8946 & 0.9546 & 0.97 & $0.31-3.04$ & 0.8946 & 0.9546 \\
\hline$<40$ vs. $51-60$ & 0.55 & $0.19-1.55$ & 0.2255 & 0.2570 & 0.55 & $0.19-1.55$ & 0.2255 & 0.2570 \\
\hline$<40$ vs. $>60$ & 1.38 & $0.41-4.61$ & 0.9216 & 0.6004 & 1.13 & $0.35-3.60$ & 0.7045 & 0.8354 \\
\hline $40-50$ vs. $51-60$ & 0.56 & $0.21-1.53$ & 0.3856 & 0.2586 & 0.56 & $0.21-1.53$ & 0.3856 & 0.2586 \\
\hline $40-50$ vs. $>60$ & 1.07 & $0.34-3.34$ & 0.8778 & 0.9020 & 0.93 & $0.31-2.78$ & 0.7200 & 0.9002 \\
\hline $51-60$ vs. $>60$ & 2.13 & $0.76-5.95$ & 0.4031 & 0.1477 & 1.81 & $0.67-4.91$ & 0.5392 & 0.2432 \\
\hline \multicolumn{9}{|l|}{ T-classification } \\
\hline \multicolumn{9}{|l|}{ Simplified classification } \\
\hline T1 vs. T2 & 0.48 & $0.21-1.14$ & 0.0973 & 0.0956 & 0.52 & $0.22-1.21$ & 0.1309 & 0.1288 \\
\hline T1 vs. T4 & 0.08 & $0.96 \mathrm{E}-2-0.72$ & 0.0125 & 0.0238 & 0.10 & $0.01-0.80$ & 0.0146 & 0.0302 \\
\hline $\mathrm{T} 2$ vs. T4 & 0.47 & $0.09-2.40$ & 0.3304 & 0.3627 & 0.47 & $0.09-2.40$ & 0.3304 & 0.3627 \\
\hline \multicolumn{9}{|l|}{ Extended classification } \\
\hline T1a vs. T1b & 0.17 & $0.60 \mathrm{E}-2-4.55$ & 0.5812 & 0.2879 & 0.22 & $0.95 \mathrm{E}-2-5.14$ & 0.6362 & 0.3473 \\
\hline T1a vs. T2a & 0.62 & $0.24-1.58$ & 0.4703 & 0.3209 & 0.67 & $0.27-1.68$ & 0.5649 & 0.3956 \\
\hline T1a vs. T2b & $0.46 \mathrm{E}-2$ & $0.26 \mathrm{E}-3-0.08$ & 0.0006 & 0.0002 & $0.75 \mathrm{E}-2$ & $0.47 \mathrm{E}-3-0.12$ & 0.0009 & 0.0005 \\
\hline T1a vs. T4 & 0.08 & $0.88 \mathrm{E}-2-0.69$ & 0.0138 & 0.0217 & 0.09 & $0.01-0.77$ & 0.0162 & 0.0281 \\
\hline T1b vs. T2a & 1.61 & $0.12-20.73$ & 0.8389 & 0.7149 & 1.61 & $0.12-20.73$ & 0.8389 & 0.7149 \\
\hline T1b vs. T2b & 0.16 & $0.01-1.58$ & 0.1489 & 0.1167 & 0.16 & $0.01-1.58$ & 0.1489 & 0.1167 \\
\hline T1b vs. T4 & 0.72 & $0.07-7.35$ & 0.4237 & 0.7822 & 0.72 & $0.07-7.35$ & 0.4237 & 0.7822 \\
\hline T2a vs. T2b & 0.08 & $0.87 \mathrm{E}-2-0.69$ & 0.0376 & 0.0222 & 0.08 & $0.87 \mathrm{E}-2-0.69$ & 0.0376 & 0.0222 \\
\hline T2a vs. T4 & 0.29 & $0.05-1.85$ & 0.1843 & 0.1916 & 0.29 & $0.05-1.85$ & 0.1843 & 0.1916 \\
\hline T2b vs. T4 & 1.60 & $0.27-9.33$ & 0.7676 & 0.6000 & 1.60 & $0.27-9.33$ & 0.7676 & 0.6000 \\
\hline \multicolumn{9}{|l|}{ Progression } \\
\hline T1a-T2a vs. T1b-T2a & 0.14 & $0.44 \mathrm{E}-2-4.29$ & 0.6031 & 0.2577 & 0.22 & $0.92 \mathrm{E}-2-5.20$ & 0.6812 & 0.347 \\
\hline T1a-T2a vs. T2a-T2b & 0.72 & $0.06-7.97$ & 0.7003 & 0.7862 & 0.80 & $0.08-8.08$ & 0.6521 & 0.8521 \\
\hline T1a-T2a vs. T2-T3 & 1.00 & $0.20-5.00$ & 0.5965 & 0.9983 & 1.11 & $0.24-5.17$ & 0.6868 & 0.8973 \\
\hline T1b-T2a vs. T2a-T2b & 7.39 & $0.15-372.40$ & 0.3173 & 0.3173 & 7.39 & $0.15-372.40$ & 0.3173 & 0.3173 \\
\hline T1b-T2a vs. T2-T3 & 1.91 & $0.12-29.45$ & 1.0000 & 0.6419 & 1.91 & $0.12-29.45$ & 1.0000 & 0.6419 \\
\hline T2a-T2b vs. T2-T3 & 2.67 & $0.14-49.75$ & 0.7893 & 0.5109 & 2.67 & $0.14-49.75$ & 0.7893 & 0.5109 \\
\hline \multicolumn{9}{|l|}{ SATB1 intensity (IHC) } \\
\hline \multicolumn{9}{|l|}{ Included LyP and SS } \\
\hline 0 vs. $1-2$ & 1.25 & $0.36-4.31$ & 0.6604 & 0.7289 & 1.10 & $0.33-3.63$ & 0.7277 & 0.8735 \\
\hline 0 vs. $3-4$ & 3.22 & $0.90-11.46$ & 0.0051 & 0.0712 & 3.22 & $0.90-11.46$ & 0.0051 & 0.0712 \\
\hline 0 vs. $5-10$ & 2.54 & $0.66-9.68$ & 0.0196 & 0.1727 & 2.54 & $0.66-9.68$ & 0.0196 & 0.1727 \\
\hline $1-2$ vs. $3-4$ & 4.14 & $1.10-15.67$ & 0.0165 & 0.0362 & 5.23 & $1.44-18.95$ & 0.0064 & 0.0118 \\
\hline $1-2$ vs. $5-10$ & 4.86 & $1.17-20.07$ & 0.0255 & 0.0291 & 5.72 & $1.49-21.97$ & 0.0110 & 0.0111 \\
\hline 3-4 vs. $5-10$ & 1.16 & $0.44-3.06$ & 0.7493 & 0.7645 & 1.16 & $0.44-3.06$ & 0.7493 & 0.7645 \\
\hline \multicolumn{9}{|l|}{ Excluded LyP and SS } \\
\hline 0 vs. $1-2$ & 1.48 & $0.40-5.46$ & 0.4383 & 0.5522 & 1.28 & $0.37-4.45$ & 0.5026 & 0.6983 \\
\hline 0 vs. $3-4$ & 3.22 & $0.90-11.46$ & 0.0051 & 0.0712 & 3.22 & $0.90-11.46$ & 0.0051 & 0.0712 \\
\hline 0 vs. $5-10$ & 2.97 & $0.74-11.95$ & 0.0109 & 0.1249 & 2.97 & $0.74-11.95$ & 0.0109 & 0.1249 \\
\hline $1-2$ vs. $3-4$ & 3.44 & $0.84-13.99$ & 0.0498 & 0.0844 & 4.51 & $1.16-17.43$ & 0.0197 & 0.0292 \\
\hline $1-2$ vs. $5-10$ & 6.29 & $1.25-31.76$ & 0.0261 & 0.0259 & 7.49 & $1.65-33.96$ & 0.0098 & 0.0090 \\
\hline $3-4$ vs. $5-10$ & 1.37 & $0.50-3.71$ & 0.3984 & 0.5388 & 1.37 & $0.50-3.71$ & 0.3984 & 0.5388 \\
\hline
\end{tabular}

HR, hazard ratio; CI, confidence interval; IHC, immunohistochemistry; SS, Sézary syndrome; LyP, lymphomatoid papulosis. Bold, statistically significant differences. ${ }^{a}$ Gehan-Breslow-Wilcoxon test; ${ }^{b} \log$-rank (Mantel-Cox) test. 
54-72\% of all CTCL cases. Nevertheless, MF is rare with an IR of 4.1-7.7/1,000,000 person-years, with a male to female IR of 1.66-1.72 $(1,2)$. The OS of MF patients is poorer than the predicted survival of the age-, gender- and race-matched control population without MF, with the exception of patients with stage IA and classified to Tla and T1b (limited patch and/ or plaque MF) (4,30-35). Kim et al (34) reported that male patients are associated with significantly poorer prognosis than female patients. By contrast, Hess Schmid et al (36) reported a significantly better prognosis in males than in females with diagnosed CTCL. Our results did not support an association between gender and survival, which is in agreement with another study performed on a large population (37). Although the results presented here showed that females had better OS and DSS than men, pairwise comparison did not show statistically significant results.

Furthermore, the data presented here indicated that older patients had better DSS, but only when comparing patients aged 40-50 years and $>60$ years at the time of diagnosis. However, in several large studies, advanced age at the time of diagnosis was found to be an independent negative prognostic factor $(34,35,37)$.

Multiple large population studies have also sought to identify clinical factors predictive of survival in patients with MF and SS. These risk factors include basic demographics, skin $T$ stage, the presence of extra-cutaneous disease, lymphadenopathy and peripheral blood involvement $(4,30-35,38-42)$. Other factors have also been proposed as potentially prognostic, and include: large-cell transformation, levels of serum lactate dehydrogenase, $\beta 2$-microglobulin, eosinophilia and serum IL-2 receptor (43-46). There are currently 20 TNMB categories: 6 skin stages (T1a, T1b, T2a, T2b, T3 and T4), 7 nodal stages (N0, N1a, N1b, N2a, N2b, N3, Nx), 2 metastatic stages (M0, M1), 5 blood stages (B0a, B0b, B1a, B1b and B2) which are then used to record 9 stages from IA to IVB $(35,47,48)$. In the present study, we concentrated only on T-classification. Our results indicated statistically lower OS and DSS in patients with diagnosed T4 stage than T1. Moreover, DSS was also statistically less frequent in T4 patients as compared to patients with $\mathrm{T} 2$ stage. The results of extended T-classification analysis are in accordance with the results of Agar et al (35) and showed that the presence of cutaneous plaques (T1a) are characterized by considerably poorer OS as compared with patients with patches only (T2a). Although our study did not reveal statistically significant differences between Tla and T1b patients, it may prove difficult to consistently distinguish thick from thin plaques on the basis of histologic criteria. However, Martí et al (49) and Zackheim (4) proved that thick plaques are associated with a poor prognosis. Similarly, results presented here indicated poorer OS and DSS in patients with T4 as compared to both T1a and T2a. As was shown by Kim et al (34), the RDP deteriorated with more advanced $\mathrm{T}$-classification, with a greater risk in patients with $\mathrm{T} 2$ compared with $\mathrm{T} 1$ patients and in $\mathrm{T} 3$ or T4 compared with T2 patients. In our study, the analysis of pairwise comparison of simplified T-classification also showed greater RDP in T2 (only 10 and 20 years) and T4 (only 5 and 10 years) patients as compared with patients diagnosed at T1 stage. Furthermore, we showed statistically significant poorer likelihood of RDP with T stage, with indication that patients with diagnosed $\mathrm{T} 2 \mathrm{~b}$ had lower risk of progression. Additionally, Kim et al (34) published data that patients with T3 and T4 disease had a similar RDP. Although our results of disease progression are comparable to those reported by the Dutch group of 309 patients, American group of 525 patients, and UK group of 1,502 patients, the analysis presented by van Doorn et al (33) did not define disease progression in patients with progression from $\mathrm{T} 1$ to $\mathrm{T} 2, \mathrm{~T} 1$ or $\mathrm{T} 2$ to $\mathrm{T} 4$ stages and research by Kim et al (34) and Agar et al (35) involved a relatively larger population. In contrast to the results presented by Kim et al (34), our study presented much longer median time from diagnosis to disease progression (or end of observation) by T-classification in T1, T2 and T4: 8.0 years for $\mathrm{T} 1$ stage, 6.0 years for T2 stage, and 8.0 years for T4 stage. For T3 disease, the median was similar (2.0 years).

SATB1 was the first matrix associated region of DNA (MAR)-binding protein (MARBP) restricted to cell type and is expressed predominantly in thymocytes $(12,16)$. It has been shown that SATB1 is organized into a cage-like network anchoring loops of heterochromatin and tethering specialized DNA sequences and serves as a global platform for the assembly of chromatin remodeling and/or modifying complexes with the anchored genomic loci (50). It has also been noted that depending on its post-translational modifications, SATB1 has the ability to activate or suppress multiple genes (51). Furthermore, SATB1 forms a functional architecture within the cell nucleus, referred to as the SATB1 network, and functions as a regulatory network of gene expression $(16,52,53)$. Moreover, it has been suggested that SATB1 binds to the minor groove of DNA specifically recognizing a unique group of AT-rich DNA sequences $(12,16)$. Yasui et al $(52)$ showed that SATB1 acts as a docking site for chromatin remodeling/ modifying factors such as ISWI, ASF1 and NURD complex containing HDAC1. Our previous study showed the colocalization of SATB1 and F-actin in the transcriptional active regions of the cell nucleus after apoptotic cell death induction and that this functional interaction was observed between SATB1 and more densely organized nuclear F-actin structures at the border between condensed and decondensed chromatin (25). This contributes to the hypothesis that nuclear SATB1 is involved in chromatin remodeling associated with transcriptional processes during active cell death. The new concept of active organization of cell nucleus states that the chromatin enables coordinated regulation of expression simultaneously in many genes (11).

Several studies have shown that the SATB1 protein is expressed in cells changing their function, e.g. in differentiating progenitor cells (54-56). The typical example of this process is the maturation of thymocytes into T lymphocytes (16). In the present study, we expanded our previous research on the role of SATB1 in the clinical course of CTCLs (11). We showed here that both mean survival and disease-specific mean survival were higher in patients characterized with moderate or high expression of SATB1. Furthermore, a similar correlation was observed after excluding SS and LyP from SATB1-positive and -negative groups. Moreover, the SATB1-positive patients had increased OS and DSS accomplished with increase in the likelihood of survival, as compared to patients with a lack or low SATB1 expression. Additionally, the present study demonstrated that patients characterized by even moderate 
expression of SATB1 survived longer than patients without its expression. Our results also indicated that SATB1-positive patients, in contrast to SATB1-negative patients, were characterized by lower RDP and SATB1-positive patients stayed longer in each $\mathrm{T}$ stage. This contributes to the results obtained by Wang et al (7), which state that deficiency in SATB1 expression causes apoptosis resistance.

Various levels of SATB1 expression have been found in different types of tumors and many studies underline its important role in pathogenesis but also as a prognostic factor (11,50,57-62), revealing that the role of SATB1 in tumors is complicated and tumor-specific (63). To confirm the results obtained by Wang et al (7) and to examine the possible mechanism by which patients with SS have poorer prognosis, we analyzed the changes in AICD of Jurkat cells after SATB1 downregulation. As we showed, the SATB1-downregulated cells were characterized by increased resistance to apoptosis. Bayer et al (64) demonstrated that FoxP3 negatively regulates SATB1 in regulatory $\mathrm{T}$ cells (Treg) and that suppression of SATB1 is required for their suppressive function and inhibition of effector differentiation. As has been shown, FoxP3 suppresses transcription of SATB1 by directly attaching to SATB1 locus. It has also been demonstrated that SATB1 is involved in the negative regulation of IL-2R $\alpha(51,52)$. Features of Treg cells suggest their role in the immunopathology of CTCL and may be strong candidates for the explanation of the immunosuppression that accompanies the evolution of the disease (65). The in vitro study by Berger et al (65) revealed that CTCL cells adopt a Treg phenotype $\left(\mathrm{CD} 25^{+} / \mathrm{CTLA}^{+}\right.$ and $\mathrm{FoxP}^{+}$) after interaction with dendritic cells loaded with apoptotic cells. Another study indicated a poorer prognosis for Sézary patients with the expression of FoxP3 (66). By contrast, Heid et al (67) showed a better prognosis for the group of patients with high FoxP3 expression. However, the groups were too small for a statistical comparison. We suggest here that clinical relevance of the correlation of FoxP3 and SATB1 expression needs to be confirmed in a larger cohort of CTCL patients, including large numbers of well-characterized Sézary patients.

In conclusion, the present study revealed that positive expression of SATB1 correlates with better prognosis of CTCL patients. Since SATB1 is strongly up- or downregulated in various types of cancer, it is a suitable candidate as a prognostic tool or an immunotherapeutic target.

\section{Acknowledgements}

This study was supported by the Polish National Science Center (NCN), grant no. N N401 596040.

\section{References}

1. Bradford PT, Devesa SS, Anderson WF and Toro JR: Cutaneous lymphoma incidence patterns in the United States: a populationbased study of 3884 cases. Blood 113: 5064-5073, 2009.

2. Criscione VD and Weinstock MA: Incidence of cutaneous T-cell lymphoma in the United States, 1973-2002. Arch Dermatol 143: 854-859, 2007.

3. Pham-Ledard A, Prochazkova-Carlotti M, Laharanne E, Vergier B, Jouary T, Beylot-Barry M and Merlio JP: IRF4 gene rearrangements define a subgroup of CD30-positive cutaneous T-cell lymphoma: a study of 54 cases. J Invest Dermatol 130: $816-825,2010$
4. Zackheim HS: Cutaneous T cell lymphoma: update of treatment. Dermatology 199: 102-105, 1999.

5. Marszałek A, Grzanka A, Grzanka D and Placek W: Correct answer to the quiz. Check your diagnosis Mycosis fungoides case report and short overview of the literature. Pol J Pathol 61: 54-61, 2010.

6. Al Hothali GI: Review of the treatment of mycosis fungoides and Sézary syndrome: a stage-based approach. Int J Health Sci 7: 220-239, 2013

7. Wang Y, Su M, Zhou LL, Tu P, Zhang X, Jiang X and Zhou Y: Deficiency of SATB1 expression in Sezary cells causes apoptosis resistance by regulating FasL/CD95L transcription. Blood 117: 3826-3835, 2011.

8. Zackheim HS: Treatment of mycosis fungoides/Sezary syndrome: the University of California, San Francisco (UCSF) approach. Int J Dermatol 42: 53-56, 2003.

9. Costantini P, Jacotot E, Decaudin D and Kroemer G: Mitochondrion as a novel target of anticancer chemotherapy. J Natl Cancer Inst 92: 1042-1053, 2000.

10. Trautinger F, Knobler R, Willemze R, et al: EORTC consensus recommendations for the treatment of mycosis fungoides/Sézary syndrome. Eur J Cancer 42: 1014-1030, 2006.

11. Grzanka A, Grzanka D, Gagat M, Tadrowski T, SokołowskaWojdyło M, Marszałek A and Placek W: Correlation of SATB1 expression with clinical course of cutaneous T-cell lymphomas. Pol J Pathol 63: 101-105, 2012.

12. Dickinson LA, Joh T, Kohwi Y and Kohwi-Shigematsu T: A tissue-specific MAR/SAR DNA-binding protein with unusual binding site recognition. Cell 70: 631-645, 1992.

13. Galande S, Purbey PK, Notani D and Kumar PP: The third dimension of gene regulation: organization of dynamic chromatin loopscape by SATB1. Curr Opin Genet Dev 17: 408-414, 2007.

14. Purbey PK, Singh S, Notani D, Kumar PP, Limaye AS and Galande S: Acetylation-dependent interaction of SATB1 and CtBP1 mediates transcriptional repression by SATB1. Mol Cell Biol 29: 1321-1337, 2009.

15. Liu J, Barnett A, Neufeld EJ and Dudley JP: Homeoproteins CDP and SATB1 interact: potential for tissue-specific regulation. Mol Cell Biol 19: 4918-4926, 1999.

16. Alvarez JD, Yasui DH, Niida H, Joh T, Loh DY and KohwiShigematsu T: The MAR-binding protein SATB1 orchestrates temporal and spatial expression of multiple genes during T-cell development. Genes Dev 14: 521-535, 2000.

17. Meng W-J, Yan H, Zhou B, et al: Correlation of SATB1 overexpression with the progression of human rectal cancer. Int $\mathrm{J}$ Colorectal Dis 27: 143-150, 2012.

18. Han B, Luan L, Xu Z and Wu B: Expression and biological roles of SATB1 in human bladder cancer. Tumour Biol 34: 2943-2949, 2013.

19. Mao L, Yang C, Wang J, Li W, Wen R, Chen J and Zheng J: SATB1 is overexpressed in metastatic prostate cancer and promotes prostate cancer cell growth and invasion. J Transl Med 11: 111, 2013.

20. Shen Z, Zeng Y, Guo J, et al: Over-expression of the special AT rich sequence binding protein 1 (SATB1) promotes the progression of nasopharyngeal carcinoma: association with EBV LMP-1 expression. J Transi Med 11: 217, 2013.

21. Ordinario E, Han H-J, Furuta S, et al: ATM suppresses SATB1induced malignant progression in breast epithelial cells. PloS One 7: e51786, 2012.

22. Wang Q, Qian J, Wang F and Ma Z: Cellular prion protein accelerates colorectal cancer metastasis via the Fyn-SP1-SATB1 axis. Oncol Rep 28: 2029-2034, 2012.

23. Fang XF, Hou ZB, Dai XZ, et al: Special AT-rich sequencebinding protein 1 promotes cell growth and metastasis in colorectal cancer. World J Gastroenterol 19: 2331-2339, 2013.

24. Kobierzycki C, Wojnar A and Dziegiel P: Expression of SATB1 protein in the ductal breast carcinoma tissue microarrays preliminary study. Folia Histochem Cytobiol 51: 333-338, 2013.

25. Grzanka D, Gagat $M$ and Izdebska M: Involvement of the SATB1/F-actin complex in chromatin reorganization during active cell death. Int J Mol Med 33: 1441-1450, 2014.

26. Edelson RL: Cutaneous T cell lymphoma: mycosis fungoides, Sézary syndrome, and other variants. J Am Acad Dermatol 2: 89-106, 1980.

27. Abel EA: Clinical features of cutaneous T-cell lymphoma. Dermatol Clin 3: 647-664, 1985.

28. Willemze R, Kerl H, Sterry W, et al: EORTC classification for primary cutaneous lymphomas: a proposal from the Cutaneous Lymphoma Study Group of the European Organization for Research and Treatment of Cancer. Blood 90: 354-371, 1997. 
29. Willemze R, Jaffe ES, Burg G, et al: WHO-EORTC classification for cutaneous lymphomas. Blood 105: 3768-3785, 2005.

30. Sausville EA, Eddy JL, Makuch RW, et al: Histopathologic staging at initial diagnosis of mycosis fungoides and the Sézary syndrome. Definition of three distinctive prognostic groups. Ann Intern Med 109: 372-382, 1988.

31. Kim YH, Chow S, Varghese A and Hoppe RT: Clinical characteristics and long-term outcome of patients with generalized patch and/or plaque (T2) mycosis fungoides. Arch Dermatol 135: 26-32, 1999.

32. Weinstock MA and Reynes JF: The changing survival of patients with mycosis fungoides: a population-based assessment of trends in the United States. Cancer 85: 208-212, 1999.

33. van Doorn R, van Haselen CW, van Voorst Vader PC, et al Mycosis fungoides: disease evolution and prognosis of 309 Dutch patients. Arch Dermatol 136: 504-510, 2000.

34. Kim YH, Liu HL, Mraz-Gernhard S, Varghese A and Hoppe RT: Long-term outcome of 525 patients with mycosis fungoides and Sezary syndrome: clinical prognostic factors and risk for disease progression. Arch Dermatol 139: 857-866, 2003.

35. Agar NS, Wedgeworth E, Crichton S, et al: Survival outcomes and prognostic factors in mycosis fungoides/Sézary syndrome: validation of the revised International Society for Cutaneous Lymphomas/European Organisation for Research and Treatment of Cancer staging proposal. J Clin Oncol 28: 4730-4739, 2010.

36. Hess Schmid M, Dummer R, Kempf W, Hilty N and Burg G: Mycosis fungoides with mucinosis follicularis in childhood Dermatology 198: 284-287, 1999.

37. Talpur R, Singh L, Daulat S, et al: Long-term outcomes of 1,263 patients with mycosis fungoides and Sézary syndrome from 1982 to 2009. Clin Cancer Res 18: 5051-5060, 2012.

38. Vicente A, Martí RM, Martín E, Estrach T, Herrero C and Mascaró JM: Mycosis fungoides with oral involvement. Int J Dermatol 30: 864-866, 1991.

39. Vonderheid EC,Diamond LW, van Vloten WA, et al: Lymph node classification systems in cutaneous T-cell lymphoma. Evidence for the utility of the Working Formulation of Non-Hodgkin's Lymphomas for Clinical Usage. Cancer 73: 207-218, 1994.

40. Bernengo MG, Quaglino P, Novelli M, et al: Prognostic factors in Sézary syndrome: a multivariate analysis of clinical, haematological and immunological features. Ann Oncol 9: 857-863, 1998.

41. Diamandidou E, Colome M, Fayad L, Duvic M and Kurzrock R: Prognostic factor analysis in mycosis fungoides/Sézary syndrome. J Am Acad Dermatol 40: 914-924, 1999.

42. Fraser-Andrews EA, Woolford AJ, Russell-Jones R, Seed PT and Whittaker SJ: Detection of a peripheral blood T cell clone is an independent prognostic marker in mycosis fungoides. J Invest Dermatol 114: 117-121, 2000.

43. Wasik MA, Vonderheid EC, Bigler RD, Marti R, Lessin SR, Polansky $M$ and Kadin ME: Increased serum concentration of the soluble interleukin-2 receptor in cutaneous T-cell lymphoma. Clinical and prognostic implications. Arch Dermatol 132: 42-47, 1996.

44. Diamandidou E, Colome-Grimmer M, Fayad L, Duvic M and Kurzrock R: Transformation of mycosis fungoides/Sezary syndrome: clinical characteristics and prognosis. Blood 92: 1150-1159, 1998.

45. Vergier B, de Muret A, Beylot-Barry M, et al: Transformation of mycosis fungoides: clinicopathological and prognostic features of 45 cases. French Study Group of Cutaneous Lymphomas. Blood 95: 2212-2218, 2000.

46. Vidulich KA, Talpur R, Bassett RL and Duvic M: Overall survival in erythrodermic cutaneous T-cell lymphoma: an analysis of prognostic factors in a cohort of patients with erythrodermic cutaneous T-cell lymphoma. Int J Dermatol 48: 243-252, 2009.

47. Olsen E, Vonderheid E, Pimpinelli N, et al: Revisions to the staging and classification of mycosis fungoides and Sezary syndrome: a proposal of the International Society for Cutaneous Lymphomas (ISCL) and the cutaneous lymphoma task force of the European Organization of Research and Treatment of Cancer (EORTC). Blood 110: 1713-1722, 2007.
48. Scarisbrick JJ, Kim YH, Whittaker SJ, Wood GS, Vermeer MH, Prince HM and Quaglino P: Prognostic factors, prognostic indices and staging in mycosis fungoides and Sézary syndrome: where are we now? Br J Dermatol 170: 1226-1236, 2014.

49. Martí RM, Estrach T, Reverter JC and Mascaró JM: Prognostic clinicopathologic factors in cutaneous T-cell lymphoma. Arch Dermatol 127: 1511-1516, 1991.

50. Han HJ, Russo J, Kohwi Y and Kohwi-Shigematsu T: SATB1 reprogrammes gene expression to promote breast tumour growth and metastasis. Nature 452: 187-193, 2008.

51. Pavan Kumar P, Purbey PK, Sinha CK, Notani D, Limaye A Jayani RS and Galande S: Phosphorylation of SATB1, a global gene regulator, acts as a molecular switch regulating its transcriptional activity in vivo. Mol Cell 22: 231-243, 2006.

52. YasuiD,MiyanoM,Cai S, Varga-WeiszPandKohwi-Shigematsu T: SATB1 targets chromatin remodelling to regulate genes over long distances. Nature 419: 641-645, 2002.

53. Cai S, Han HJ and Kohwi-Shigematsu T: Tissue-specific nuclear architecture and gene expression regulated by SATB1. Nat Genet 34: 42-51, 2003.

54. Notani D, Limaye AS, Kumar PP and Galande S: Phosphorylation-dependent regulation of SATB1, the higher-order chromatin organizer and global gene regulator. Methods Mol Biol 647: 317-335, 2010

55. Satoh Y, Yokota T, Sudo T, et al: The Satb1 protein directs hematopoietic stem cell differentiation toward lymphoid lineages. Immunity 38: 1105-1115, 2013.

56. Will B, Vogler TO, Bartholdy B, et al: Satb1 regulates the selfrenewal of hematopoietic stem cells by promoting quiescence and repressing differentiation commitment. Nat Immunol 14: 437-445, 2013.

57. Agrelo R, Souabni A, Novatchkova M, et al: SATB1 defines the developmental context for gene silencing by Xist in lymphoma and embryonic cells. Dev Cell 16: 507-516, 2009.

58. Zhou LY, Liu F, Tong J, Chen QQ and Zhang FW: Expression of special AT-rich sequence-binding protein $\mathrm{mRNA}$ and its clinicopathological significance in non-small cell lung cancer. Nan Fang Yi Ke Da Xue Xue Bao 29: 534-537, 2009 (In Chinese).

59. Li QQ, Chen ZQ, Xu JD, Cao X-X, Chen Q, Liu XP and Xu ZD: Overexpression and involvement of special AT-rich sequence binding protein 1 in multidrug resistance in human breast carcinoma cells. Cancer Sci 101: 80-86, 2010.

60. Lu X, Cheng C, Zhu S, et al: SATB1 is an independent prognostic marker for gastric cancer in a Chinese population. Oncol Rep 24: 981-987, 2010

61. Zhao XD, Ji W, Zhang W, He LX, Yang J, Liang HJ and Wang LL: Overexpression of SATB1 in laryngeal squamous cell carcinoma. ORL J Otorhinolaryngol Relat Spec 72: 1-5, 2010.

62. Chen H, Takahara M, Oba J, et al: Clinicopathologic and prognostic significance of SATB1 in cutaneous malignant melanoma. J Dermatol Sci 64: 39-44, 2011.

63. Zhang L, Cheng F, He R, Chen H, Liu Y and Sun J: Inhibition of SATB1 by shRNA suppresses the proliferation of cutaneous malignant melanoma. Cancer Biother Radiopharm 29: 77-82, 2014.

64. Bayer AL, Chirinos J, Cabello C, Yang J, Matsutani T, Malek TR and Levy RB: Expansion of a restricted residual host T reg-cell repertoire is dependent on IL-2 following experimental autologous hematopoietic stem transplantation. Eur J Immunol 41: 3467-3478, 2011.

65. Berger CL, Tigelaar R, Cohen J, Mariwalla K, Trinh J, Wang N and Edelson RL: Cutaneous T-cell lymphoma: malignant proliferation of T-regulatory cells. Blood 105: 1640-1647, 2005.

66. Capriotti E, Vonderheid EC, Thoburn CJ, Wasik MA, Bahler DW and Hess AD: Expression of T-plastin, FoxP3 and other tumorassociated markers by leukemic T-cells of cutaneous T-cell lymphoma. Leuk Lymphoma 49: 1190-1201, 2008.

67. Heid JB, Schmidt A, Oberle N, Goerdt S, Krammer PH, Suri-Payer E and Klemke CD: FOXP ${ }^{+} \mathrm{CD} 25^{-}$tumor cells with regulatory function in Sézary syndrome. J Invest Dermatol 129: 2875-2885, 2009. 